九州大学学術情報リポジトリ

Kyushu University Institutional Repository

\title{
A Revision of the Subgenus Andrena of the Genus Andrena of Eastern Asia (Hymenoptera: Apoidea: Andrenidae)
}

Xu, Huan- $\mathrm{i}$

Department of Entomology, College of Agriculture and Biotechnology, China Agricultural University

Tadauchi, Osamu

Department of Biology, Faculty of Sciences, Kyushu University

https://doi.org/10.5109/22056

出版情報 : 九州大学大学院農学研究院紀要. 57 (1)，pp.97-114，2012-02. Faculty of Agriculture， Kyushu University

バージョン :

権利関係 : 


\title{
A Revision of the Subgenus Andrena of the Genus Andrena of Eastern Asia (Hymenoptera: Apoidea: Andrenidae)
}

\author{
XU Huan-li* and Osamu TADAUCHI
}

\author{
Laboratory of Entomology, Division of Zoology \& Entomology, Department of \\ Agricultural Bioresource Sciences, Faculty of Agriculture, \\ Kyushu University, Fukuoka 812-8581, Japan \\ (Received October 31, 2011 and accepted November 9, 2011)
}

\begin{abstract}
The subgenus Andrena of the genus Andrena from eastern Asia is revised and 28 species are recognized. Seven new species Andrena (Andrena) beneficalla n. sp., A. (Andrena) cristatolabra n. sp., A. (Andrena) gilvithoracica n. sp., A. (Andrena) kunmingica n. sp., A. (Andrena) maerkangensis n. sp., A. (Andrena) subhondoica n. sp. and A. (Andrena) tumorensis n. sp. are described. Five species Andrena (Andrena) aburana Hirashima, A. (Andrena) benefica Hirashima, A. (Andrena) brevihirtiscopa Hirashima, A. (Andrena) helvola Linnaeus, A. (Andrena) scutellaris Morawitz are recorded from China for the first time. The males of Andrena (Andrena) jeholensis Yasumatsu and A. (Andrena) scutellaris Morawitz are described for the first time. A key to East Asian females of Andrena s. str. is given.
\end{abstract}

Key words: Andrenidae, East Asia, Hymenoptera, new species, revision

\section{INTRODUCTION}

The typical subgenus of Andrena s. str. is characterized in both sexes by the usual lack of pale tergal hair bands, and the pronotal humaeral angle with a well developed dorsoventral ridge. The female has the complete propodeal corbicula with few or no internal hairs. The male usually has a prominent basoventral tooth on the mandible and a black clypus (LaBerge, 1964). LaBerge (1980) revised 31 North American species of the subgenus Andrena. In Europe, Warncke (1968) listed 15 species in this subgenus. In eastern Asia, Tadauchi et al. (1988) revised 16 Japanese species of Andrena s. str. In Russian Far East, Osytshnjuk (1995) gave a key to 11 species including 2 subspecies of $A$. (Andrena) lapponica in this subgenus. Recently, Scheuchl (2005) described 2 new species Andrena (Andrena) orchidea and A. (Andrena) solutiscopa from Yunnan, China, Tadauchi and Matsumura (2007) described a new species, A. (Andrena) sagarmathana from Nepal, and Tadauchi (2011) described a new species, A. (Andrena) katakuri from Japan. The holarctic Andrena s. str. is represented by 41 species in the Palaearctic Region and 29 species in Nearctic region (Ascher \& Packling, 2011), in which, Andrena (Andrena) clarkella (Kirby) is a holarctic species. In this study, we examined species deposited in the Institute of Zoology, Academia Sinica and the Entomological Laboratory, Kyushu University, and recognized 28 species of Andrena from eastern Asia. Seven new species, Andrena (Andrena) beneficalla n. sp., A. (Andrena) cristatolabra n. sp., A. (Andrena) gilvithoracica n. sp., A. (Andrena) kunmingica n. sp., A. (Andrena)

* Department of Entomology, College of Agriculture and Biotechnology, China Agricultural University, Beijing 100193, China

* Corresponding author (H-l. Xu, E-mail: hanabati@cau.edu.cn) maerkangensis n. sp., A. (Andrena) subhondoica $\mathrm{n}$. sp., A. (Andrena) tumorensis n. sp. are described. Five species, Andrena (Andrena) aburana Hirashima, A. (Andrena) benefica Hirashima, A. (Andrena) brevihirtiscopa Hirashima, A. (Andrena) helvola Linnaeus, A. (Andrena) scutellaris Morawitz are recorded from China for the first time. The males of Andrena (Andrena) jeholensis Yasumatsu and A. (Andrena) scutellaris Morawitz are described for the first time. A key to East Asian females of Andrena s. str. is given, but two Asian species, A. (Andrena) orchidea and A. (Andrena) solutiscopa, which we could not study, are not included in this paper. Specimens were borrowed from the Institute of Zoology, Academia Sinica (Beijing) and the Entomological Laboratory, Kyushu University (Fukuoka). The holotypes and some paratypes will be deposited in the Institute of Zoology, Academia Sinica, Beijing, and part of paratypes will be deposited in the Entomological Laboratory, Kyushu University, Fukuoka.

\section{Subgenus Andrena Fabricius}

Andrena Fabricius, 1775, Syst. Ent., 376; Hedicke, 1933, Mitt. Zool. Mus. Berlin, 19: 209-201; Lanham, 1949, Univ. California Publ. Ent., 8: 205-206; Hirashima, 1962, J. Fac. Agr., Kyushu Univ., 12: 123; LaBerge, 1964, Bull. Univ. Nebraska St. Mus., 4: 299-300; Warncke, 1968, Mem. Est. Mus. Zool. Univ. Coimbra, (307): 97-98; LaBerge, 1980, Trans. Amer. ent. Soc., 106: 396; Tadauchi et al., 1987, J. Fac. Agr., Kyushu Univ., 31: 11. Type species: Apis helvola L., 1758, by designation of Viereck, 1912. Anthrena Illiger, 1801, Mag. Insect., 1: 127. Anthocharessa Gistel, 1850, Isis, 6: 82.

Diagnosis: Medium-sized to large bees; facial quadrangle broader than long or quadrate; clypeus black; subgenal coronet present; malar space usually evident; pronotum with humeral angle and ridge; propodeal corbicula completely developed; middle basitarsi normal; three 
submarginal cells present; metasomal terga rarely with apical hair bands or poorly formed. Male head large; mandible with basal inferior tooth or angle; genal area broadened and angulate posteriorly; sterna with short, complete subapical fimbriae.

Key to female species of the subgenus Andrena $s$. str. in eastern Asia

1. Tibial scopal hairs rather short to short, fine ...........2

- Tibial scopal hairs long, coarse ................................. 3

2. First flagellar segment as long as flagellar segment 2 plus 3; process of labrum broad, entire; hind tibia cuneate at apex; propodeum with dorsal face shagreened ........................ brevihirtiscopa Hirashima

- First flagellar segment shorter than flagellar segment 2 plus 3 ; process of labrum narrow, emarginate; hind tibia normal; propodeum with dorsal face finely granulate ..................... mali Tadauchi et al.

3. Metasomal terga with rather long and dense hairs, usually obscuring tergal segments

- Metasomal terga with relatively short and dense to sparse hairs or scanty, not obscuring tergal segments ....................................................................

4. Clypeus densely punctate with dense and small punctures, without median longitudinal impunctate line; propodeum with enclosure evenly tessellate; pygidial plate V-shaped ................ genalis Morawitz

- Clypeus broadly smooth and shiny with sparse and large punctures, with median broad impunctate space; propodeal enclosure rugulate basally; pygidial plate U-shaped .......... mikado Strand et Yasumatsu

5. Hind tibia ferruginous with orange scopal hairs; hairs on head, thorax and metasomal terga long, dense, terga with colored apical fasciae; [clypeus broadly smooth and shiny with broad impunctate median space]. nawai Cockerell

- Hind tibia brown to black, if ferruginous, the metasomal terga with abundant decumbent yellow hairs, tibial scopal hairs various in color; hairs on metasomal terga sparse or scanty .................................... 6

6. Mesoscutum weakly tessellate, shiny with fine punctures; [clypeus weakly convex, sparsely punctate medially with large punctures, median impunctate space distinct; process of labrum large, entire; tibia ferruginous] ..................................esakii Hirashima

- Mesoscutum densely tessellate, surface opaque ..... 7

7. Mesoscutum coarsely and minutely punctate posteromedially, weakly roughened; [clypeus sparsely punctate with broad impunctate space, surface broadly shiny apicomedially; tibial scopal hairs white; metasomal terga with scanty hairs]

sakagamii Tadauchi et al.

- Mesoscutum densely tessellate with punctures sparsely and minutely, not roughened .................... 8

8. Facial quadrangle broader than long ...................... 9

- Facial quadrangle as broad as long ........................ 21

9. Clypeus tessellate nearly all over except median impunctate space, crowdedly punctate; process of labrum subtriangular, abruptly narrowed near apex; integument with abundant hairs, mainly dull white; medium sized aino Tadauchi et al.

- Clypeus at least shiny apically; process of labrum trapezoidal, entire or emarginate ......................... 10

10. Length $12-14.5 \mathrm{~mm}$; hairs on clypeus brown; tibial scopal hairs brown to black ...................................11

- Length less $12 \mathrm{~mm}$; if over $12 \mathrm{~mm}$, then basitarsus yellow; hairs on clypeus white; tibial scopal hairs various in color

14

11. First flagellar segment longer than flagellar segment 2 plus 3; mesoscutum and scutellum with black hairs; [process of labrum small, emarginate; metasomal terga weakly and minutely punctate]

jeholensis Yasumatsu

- First flagellar segment as long as flagellar segment 2 plus 3; mesoscutum and scutellum with yellow hairs

12

12. Process of labrum narrow, entire; [clypeus with moderate punctures separated by $0.5-1$ puncture width; metasomal terga with brown hairs] gilvothoracica n. sp.

- Process of labrum broad, weakly emarginate apically

13. Clypeus with moderate punctures separated by 0.5 puncture width, surface broadly shiny apically; metasomal terga with scanty brown hairs

tumorensis n. sp

- Clypeus with moderate punctures separated by 1 puncture width, surface tessellate; metasomal terga with yellow hairs ishiharai Hirashima

14. Galea smooth and shiny, surface with microscopic

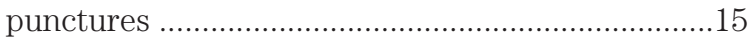

- Galea tessellate, surface impunctate .................... 18

15. Malar space about $1 / 3$ time as long as basal mandibular width; tibial scopal hairs black; metasomal terga sparsely and minutely punctate

scutellaris Morawitz

- Malar space short, about 1/6 time as long as basal mandibular width or linear; tibial scopal hairs white; metasomal terga nearly impunctate ........................16

16. Malar space linear; metasomal terga with distinct white apical fasciae; [length 8-8.5 mm]

beneficalla $\mathrm{n}$. sp.

- Malar space short; metasomal terga with obscure apical fasciae ........................................................ 17

17. Clypeus with moderate punctures separated by 0.5 puncture width; scutellum shiny with fine punctures; mesoscutum with dense white hairs admixed with a few black hairs ................ subhondoica n. sp.

- Clypeus with moderate punctures separated by 1 puncture width; scutellum densely tessellate with punctures obscured; mesoscutum with dull white to pale fulvous hairs hondoica Hirashima

18. Hairs on mesoscutum and scutellum brown; propodeal enclosure well defined by raised lateral sutures, length $13.5 \mathrm{~mm}$ maerkangensis $\mathrm{n}$. sp.

- Hairs on mesoscutum and scutellum not brown; propodeal enclosure defined by weakly raised lateral sutures, length less than $10 \mathrm{~mm}$............................. 19

19. Labrum with laminate crista below; process of labrum deeply emarginate; clypeus with irregular 
impunctate space; metasomal terga with broad apical fasciae cristatolabra n. sp.

- Labrum with weak crista below; process of labrum entire; clypeus with broad impunctate space .......20

20. Scutellum and metasomal terga less shiny; clypeus with sparse punctures, broadly shiny at apical half benefica Hirashima

- Scutellum and metasomal terga shinier; clypeus with dense punctures, narrowly shiny apically babai Tadauchi et al.

21. Clypeus strongly convex, with rather sparse punctures; process of labrum deeply emarginate; propodeal enclosure evenly tessellate all over, with a median weak longitudinal line; [length $13.5 \mathrm{~mm}$ ] ..kunmingica n. sp.

- Clypeus well convex; process of labrum entire or weakly emarginate; propodeal enclosure rugulate basally; if tessellate all over, then facial quadrangle slightly broader than long and brown hairs on mesoscutum

.. 22

22. Malar space about $1 / 3$ time as long as width of basal mandible; hairs on head including clypeus brown; [clypeus broadly shiny with sparse punctures]

.lapponica shirozui Hirashima

- Malar space about 1/4-1/5 time as long as width of basal mandible; hairs on clypeus pale yellow to fulvous

23. Tibia long; propodeal enclosure strongly rugulate basally; [clypeus sparsely punctate; medium sized] longitibilis Hirashima

- Tibia relatively shorter; propodeal enclosure weakly rugulate basally 24

24. Metasomal terga weakly punctate with abundant long hairs; [process of labrum entire] ....... helvola L.

- Metasomal terga with scanty hairs or short hairs

26

25. Clypeus with moderate punctures separated by 1 puncture width, sparser apically, median impunctate space narrow; [process of labrum weakly emarginated] maukensis Matsumura

- Clypeus with large and sparse punctures, with median impunctate space broad ......................... 26

26. Process of labrum entire; clypeus less shiny; mesoscutum with fulvous hairs

saragamieensis Hirashima

- Process of labrum emarginate; clypeus broadly shiny; mesoscutum with fuscous to brown hairs aburana Hirashima

\section{Andrena (Andrena) brevihirtiscopa Hirashima}

Andrena (Andrena) brevihirtiscopa Hirashima, 1962, J. Fac. Agr., Kyushu Univ., 12: 124 [female \& male, Japan]; Hirashima, 1966, J. Fac. Agr., Kyushu Univ., 14: 100, 116 [female \& male, in key]; Tadauchi et al., 1987, J. Fac. Agr., Kyushu Univ., 31: 18; Tadauchi and Lee, 1992, Esakia, (32): 48 [Korea]; Osytshnjuk, 1995, Key Insects Russian Far East, Vol. IV, Part 1, 514, 516, 522 [female \& male, in key]; Gusenleitner and Schwarz, 2002, Entomofauna, 12(suppl.): 142-143.
Specimens examined: Holotype female and allotype male (Kyushu Univ.), Mt. Hikosan, Fukuoka, Japan, 4. v. 1937 (K. Yasumatsu). Other material: China: Heilongjiang Province: 3 females, Jingpo Lake, Mudanjiang, 23-25. v. 1993 (O. Tadauchi).

Remarks: This species is recognized by the hind tibia cuneate with scopal hairs short, the entire labral process in female. It can be separated from $A$. mali Tadauchi et al. by the process of labrum larger and entire, the first flagellar segment longer and the hind tibia cuneate in female.

Distribution: China (new record, Heilongjiang Prov.); Japan (Hokkaido, Honshu, Sado Is., Kyushu); Korea (southern Korea); Russia (Far East Area).

Floral associations: Japan: Prunus sargentii, $P$. yedoensis, Malus pumila; Acer sp.

\section{Andrena (Andrena) genalis Morawitz}

Andrena genalis Morawitz, 1880, Bull. Acad. Sci. St. Petersbourg, 26: 360 [female, Mongolia]; Yasumatsu, 1841, Peking nat. Hist. Bull., 15: 276 [in list]; Wu, 1985, Living Things Tianshan Tumorfeng Region Xinjiang, Apoidea, 139 [in list, China].

Andrena (Andrena) genalis: Xu and Tadauchi, 1997, J. Fac. Agr., Kyushu Univ., 41: 168 [redescription]; Gusenleitner and Schwarz, 2002, Entomofauna, 12(suppl.): 313-314.

Specimen examined: China, Xinjiang Uygur Autn. Region: 1 female, Alashan, Shaosu, 2,430 m, 31. vii. 1978 (X-z. Zhang).

Remarks: This species is similar to European Andrena armata (Gmelin) in having the abundant, long colored hairs on the body. The female is separated from that of armata by the deeply emarginated labral process and the densely punctated clypeus. The broad, impunctate longitudinal space on the clypeus and the entire labral process are characteristic in armata.

Distribution: China (Xinjiang Uygur Autn. Region); Mongolia.

Floral association: Not available.

\section{Andrena (Andrena) mikado Strand et Yasumatsu}

Andrena (Melandrena) mikado Strand et Yasumatsu, 1938, Mushi, 11: 67 [female, Japan].

Andrena mikado Yasumatsu, 1941, Peking nat. Hist. Bull., 15: 278 [in list].

Andrena (Andrena) mikado Hirashima, 1962, J. Fac. Agr., Kyushu Univ., 12: 127 [female \& male]; Hirashima, 1966, J. Fac. Agr., Kyushu Univ., 14: 101, 116 [female \& male, in key]. Tadauchi et al., 1987, J. Fac. Agr., Kyushu Univ., 31: 20-22; Gusenleitner and Schwarz, 2002, Entomofauna, 12(suppl.): 479-480.

Specimen examined: Holotype female (Kyushu Univ.), Sangunsan, Fukuoka Pref., Kyushu, Japan, 18. iv. 1934 (K. Yasumatsu).

Distribution: Japan (Honshu, Shikoku, Kyushu, Tsushima Is., Yakushima Is.).

Floral associations: Pieris japonica, Rhododendron 
pentaphyllum, R. metternichii; Enkianthus perulatus, Taraxacum japonicum, Salix sp.

\section{Andrena (Andrena) nawai Cockerell}

Andrena nawai Cockerell, 1913, Ann. Mag. nat. Hist., (8)11: 188 [female, Japan]; Yasumatsu, 1941, Peking nat. Hist. Bull., 15: 279 [in list].

Anthrena japonica Alfken, 1900, Ent. Nachr., 26: 178 [female, Japan].

Andrena simulans Peréz, 1905, Bull. Mus. d'Hist. Nat. Paris, 34 [male, Japan]; Cockerell, 1913, Ann. Mag. nat. Hist., (8)11: 189.

Andrena simulatilis Viereck, 1918, Proc. biol. Soc. Washington, 31: 59, n. n. for A. simulans Peréz, 1905.

Andrena nipponica Cockerell, 1922, Proc. U. S. nat. Mus., 60: 11; Yasumatsu, 1941, Peking nat. Hist. Bull., 15: 279.

Andrena japonica Alfken, 1924, Konowia, 3: 95 [male, Japan].

Andrena (Melandrena) mikado Strand et Hirashima, 1938, Mushi, 11: 67-69 [male, Japan].

Andrena (Andrena) bombiformis Yasumatsu et Hirashima, 1962, J. Fac. Agr., Kyushu Univ., 12: 133 [female, Japan]; Hirashima, 1966, J. Fac. Agr., Kyushu Univ., 14; 101 [female, in key].

Andrena (Andrena) nawai: Hirashima, 1962, J. Fac. Agr., Kyushu Univ., 12: 133 [female \& male, Japan]; Hirashima, 1966, J. Fac. Agr., Kyushu Univ., 14: 102, 106 [female \& male, in key]; Tadauchi and Hirashima, 1987, J. Fac. Agr., Kyushu Univ., 31: 24-28; Osytshnjuk, 1995, Key Insects Russian Far East, Vol. IV, Part 1, 514, 522 [female \& male, in key]; Xu and Tadauchi, 1998, Esakia, (38): 90-91; Gusenleitner and Schwarz, 2002, Entomofauna, 12(suppl.): 515516.

Andrena phytophila Strand, 1915, Ent. Mitt., 4: 73-74 [female, China]; Yasumatsu, 1941, Peking nat. Hist. Bull., 15: 279 [in list].

Specimens examined: China: Liaoning Province: 1 female, Dalian, 30. v. 1940 (S. Asahina). Jiangsu Province: 2 females, Zhenjiang, 1. iv. 1918. Beijing: 2 females, 25. iv. 1961 (S-m. Ge); 2 females, 17. iv. 1963 (S-m. Ge); 1 female, 4. v. 1964 (S-m. Ge); 1 female, 14. iv. 1973 (Y-r. Wu); 1 female, 24. iv. 1973 (S-f. Wang); 1 female, 20. iv. 1978 (S-f. Wang). Heilongjiang Province: Harbin: 2 males, 1. v. 1945; 3 females, 4. v. 1952; 1 female, 25. iv. 1953; 1 male, 29. iv. 1954; 1 female, 23. v. 1954. Shannxi Province: 1 female, Gaoping, 23. vi. 1963 (J-l. Mao). Gansu Province: 2 females, Lanzhou, 27. iv. 1955 (S-j. Ma).

Distribution: China (Shandong, Liaoning, Jiangsu, Beijing, Heilongjiang, Shannxi, Gansu Provs.); Japan (Hokkaido, Rishiri Is., Honshu, Shikoku, Kyushu); Russia (Far East area).

Floral associations: China: Pyrus ussuriensis., Paeonia suffruticosa, Malus spectabilis.

\section{Andrena (Andrena) esakii Hirashima}

Andrena (Andrena) esakii Hirashima, 1957, Mushi, 30:
49 [female, Japan]; Hirashima, 1962, J. Fac. Agr., Kyushu Univ., 12: 137 [female \& male]; Hirashima, 1966, J. Fac. Agr., Kyushu Univ., 12: 102, 116 [female \& male, in key]; Tadauchi et al., 1987, J. Fac. Agr., Kyushu Univ., 31: 28 ; Gusenleitner and Schwarz, 2002, Entomofauna, 12(suppl.): 255.

Specimen examined: Holotype female (Kyushu Univ.), Hikosan, Fukuoka Pref., Kyushu, Japan, 6. v. 1951 (Y. Hirashima).

Distribution: Japan (central Honshu, Shikoku, Kyushu).

Floral association: Acer sp.

\section{Andrena (Andrena) sakagamiii Tadauchi,} Hirashima et Matsumura

Andrena (Andrena) sakagamiii Tadauchi, Hirashima et Matsumura, 1987, J. Fac. Agr., Kyushu Univ., 31: 29-32 [female \& male, Japan]; Tadauchi and Lee, 1992, Esakia, (32): 49 [Korea]; Osytshnjuk, 1995, Key Insects Russian Far East, Vol. IV, Part 1, 516, 522 [female \& male, in key]; Gusenleitner and Schwarz, 2002, Entomofauna, 12(suppl.): 657.

Specimen examined: Holotype female (Type No. 2572, Kyushu Univ.), Yamada Spa, Niseko, Hokkaido, Japan, 20. v. 1984 (O. Tadauchi).

Distribution: Japan (Hokkaido, Okushiri Is., north Honshu); Korea (southern Korea); Russia (Far East area).

Floral association: Taraxacum officinale.

\section{Andrena (Andrena) aino Tadauchi, Hirashima et Matsumura}

Andrena (Andrena) apicata aino Tadauchi, Hirashima et Matsumura, 1987, J. Fac. Agr., Kyushu Univ., 31: 32-35 [female \& male, Japan].

Andrena (Andrena) aino: Osytshnjuk, 1995, Key Insects Russian Far East, Vol. IV, Part 1, 513, 521 [female \& male, in key]; Gusenleitner and Schwarz, 2002 , Entomofauna, 12(suppl.): 68.

Specimen examined: Holotype female (Type No. 2573, Kyushu Univ.), Obihiro, Hokkaido, Japan, 29. iv. 1975 (M. Usui).

Distribution: Japan (eastern Hokkaido); Russia (Far East area).

Floral association: Salix sp.

\section{Andrena (Andrena) jeholensis Yasumatsu}

Andrena (Chlorandrena) jeholensis Yasumatsu, Insects Jehol, 8: 43 [female, China]; Yasumatsu, 1941, Peking nat. Hist. Bull., 15: 277 [in list].

Andrena (?Chlorandrena) jeholensis Gusenleitner and Schwarz, 2002, Entomofauna, 12(suppl.): 379.

Female (description based on normal specimens, the holotype lacks abdomen) : BL 13.7-15.0 mm, WL 10.5$11.9 \mathrm{~mm}(\mathrm{n}=4)$.

Color: Flagellum reddish brown beneath; mandible 
with apical third reddened; wing membranes subhyaline, veins and pterostigma reddish yellow; tibial spurs testaceous; posterior margins of metasomal terga reddish yellow subhyaline.

Pubescence: Hairs on head dense, brown except antennal area, vertex, and genal area outer margin of eye mixed with dull white; those on clypeus 300-400 $\mu$, scanty medially; those on vertex about 800-900 $\mu$; facial fovea brown. Hairs on mesoscutum and scutellum 400-700 $\mu$, short and black medially, long and dull white marginally; those on metanotum dull white; those on mesepisternum rather long, dense and whitish; propodeal corbicula well developed, white, without internal hairs mostly; trochanteral floccus perfect, white; femoral floccus dense; tibial scopal hairs long, simple, brown in front, paler behind. Hairs on metasomal terga not so dense, pale white except terga 3-4 mixed with short, brown medially; those on terga 1-2 long, terga 2-4 with suberect dull white apically; caudal fimbria brown; sterna $2-5$ with long whitish subapical fimbriae laterally.

Structure: Head: HL/HW=0.78. HW: MsW: $M t W=4.0$ : 3.9: 4.2. Vertex shagreened above lateral ocelli, weakly tessellate above facial fovea, shiny with sparse minute PP. OOD: POD: OCD=0.8: 0.5: 0.3. FL1=FL2+3, FL2=FL3 about as long as broad, following flagellar segments longer than broad. Eyes with inner margins paralleled. Facial fovea moderate, extending to below a line at lower margins of antennal fossae, $F V L=1.4 \mathrm{~mm}$, FVW $=0.5 \mathrm{~mm}$. Supraclypeal area dulled by dense minute PP. Face above antennal fossae with weak longitudinal rugulae and coarse interrugal PP, surface dull. Facial quadrangle broader than long (about 3.0: 2.7). Clypeus well convex, surface finely tessellate, feebly shiny medially, with $\mathrm{PP} \phi 20-40 \mu$, IS=0.5, smaller and denser at extreme angle area, with median indistinct longitudinal impunctate line or lacking, $\mathrm{CPL}=1.3 \mathrm{~mm}$. Process of labrum moderate, weakly to deeply emarginate apically. Labrum apical to process convex, not sulcate, without median cristae. Lower paraocular area closely punctate with minute PP, surface shagreened. Malar space short, about one-fourth time as long as width of basal mandible. Genal area broader than eye, GW: $\mathrm{EW}=1.0$ : 0.9 , surface weakly tessellate, weakly shiny with minute PP, IS=1-2. Mesosoma: Pronotum with distinct humeral angle and ridge, surface reticularly shagreened, PP obscured. Mesoscutum densely shagreened marginally, finely tessellate posteromedially with PP $\phi 20 \mu$, IS=1. Scutellum densely shagreened posteromedially, shiny anteriorly with PP, irregular in distribution. Propodeal enclosure finely tessellate, with basal short, weak rugulae; dorsal face of propodeum roughened with obscure PP. Mesepisternum densely tessellate with weak irregular minute PP, surface shagreened. Vein 1 st $m-c u$ meeting second submarginal cell near end of cell. Metasoma: Metasomal terga weakly tessellate or almost so, weakly shiny; terga 1-4 each weakly punctate with scattered minute PP at basal two-thirds, IS=2-3 or more, apical area PP obscure; posterior depressions of terga well indicated; pygidial plate $\mathrm{V}$-shaped with large raised internal triangular area. Sterna 2-5 weakly tessel- late, shiny, finely punctate with minute PP, IS=2 mostly.

Male (new to science): BL $12.0 \mathrm{~mm}$, WL $10.5 \mathrm{~mm}$ $(n=1)$.

Color: Flagellum reddish brown beneath; mandible with about apical half reddened; wing membranes weakly infumate subhyaline, veins and pterostigma reddish brown; tibial spurs testaceous; posterior margins of metasomal terga dark reddened.

Pubescence: Hairs on head as in female, but antennal area and vertex mixed with dull yellow; those on thorax dull yellow, but mesoscutum and scutellum mixed with black, long; those on metasomal terga as in female, apical area of tergum 2 and terga 3-5 with black hairs, terga 2-4 with indistinct apical fasciae, dull white, broadly interrupted on terga 2-3; sterna 2-5 with complete, compact brown subapical fimbriae.

Structure: Head: HL/HW=0.75. HW: MsW: $M t W=4.0$ : 3.5: 3.5. Vertex sculptured as in female. OOD: POD: $\mathrm{OCD}=0.8:$ 0.5: 0.4. FL1 about as long as FL2, distinctly longer than broad, following flagellar segments lacking in the examined specimens. Eyes with inner margins subparalleled. Supraclypeal area and face above antennal fossae as in female. Facial quadrangle broader than long (about 2.9: 2.5). Clypeus weakly convex, surface with close-set PP $\phi 20-40 \mu$, IS $<0.5$, sparser apically, denser at extreme side, without median impunctate line, tessellate, $\mathrm{CPL}=1.2 \mathrm{~mm}$. Process of labrum deeply emarginate apically, surface smooth and shiny. Labrum apical to process convex as in female. Mandibles long, decussate, without basal spine. Lower paraocular area weakly tessellate, shiny, closely punctate near antennal area, sparsely punctate near inner margin of eye with PP $\phi 20 \mu$ in size. Malar space about one-fourth as long as width of basal mandible. Genal area broadened, angulated posteromedially, GW: $\mathrm{EW}=1.3$ : 0.8, surface weakly tessellate, shiny with minute PP, IS=1-1.5. Mesosoma: Pronotum with distinct humeral angle and ridge, space between ridge and post pronotal lobe with parallel rugulae. Mesoscutum, scutellum and propodeum sculptured as in female. Mesepisternum as in female but PP distinct, coarsely punctate above, sparsely punctate below. Wing venation as in female. Metasoma: Metasomal terga sculptured as in female, but surface shiner. Sterna strongly shiny, with scattered minute PP, sternum 6 weakly reflected, not emarginate apically.

Specimens examined: Holotype female (the National Science Museum, Tokyo), Wulingshan, Hebei Province, China, 2. ix. Other material: Hebei Province: 1 male and 1 female, Yangkiaping, 28. vii - 3. viii. 1937 (O. Piel); 2 females, Eastern Tomb (Xianghe). Beijing: 1 female, Donglingshan, 1,200 m, 26. viii. 1991 (L-l. Yang).

Remarks: This species is very similar to Andrena ishiharai Hirashima except in both sexes the larger in size and the black hairs on the mesoscutum and scutellum, however, it is separated from ishiharai by the process of labrum deeply emarginate especially in female. The male is separated from that of ishiharai by the FL1 about as long as FL2 and the sternum 6 weakly reflected 
apically.

Distribution: China (Beijing, Hebei Provs.).

Floral association: Not available.

\section{Andrena (Andrena) gilvithoracica n. sp.}

(Fig. 1: A-E)

Andrena (Holandrena) mediocalens (nec Cockerell): Wu, 1982, Insects Xizang, Vol. 2, 392, in part.

Female: BL $12.5 \mathrm{~mm}$, WL $11.2 \mathrm{~mm}(\mathrm{n}=1)$.

Color: Flagellum narrowly reddish yellow beneath except basal portion; mandible with apical half reddened; wing membranes subhyaline, veins and pterostigma reddish brown; tibial spurs reddish yellow; posterior margins of metasomal terga dark brown.

Pubescence: Hairs on head black; those on clypeus 400-500 $\mu$, sparse; those on antennal area long and dense; those on vertex about $700-800 \mu$; those on genal area
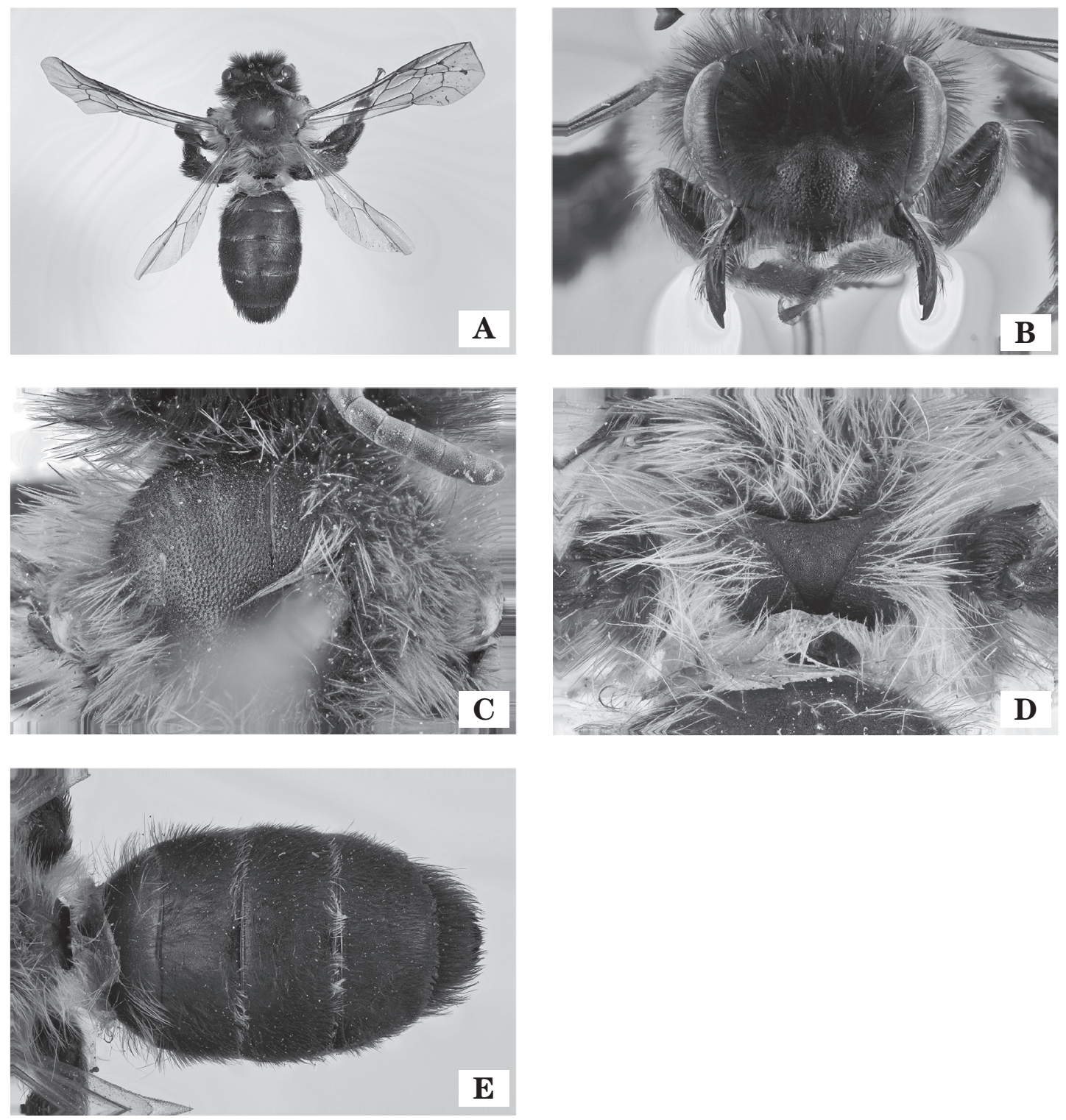

Fig. 1. Andrena (Andrena) gilvithoracica, n. sp., female. A: general habitus in dorsal view; B: head in frontal view; C: mesoscutum; D: propodeum; E: metasomal terga. black mixed with fulvous; facial fovea black. Hairs on thorax dense, fulvous; those on mesoscutum 500-700 $\mu$; those on scutellum $900 \mu$; those on mesepisternum $1,100 \mu$; propodeal corbicula well developed; trochanteral floccus perfect, yellow; femoral floccus dense; tibial scopal hairs moderately long, simple, black. Hairs on metasomal terga dense, black except tergum 1 with long pale yellow; those on tergum 2 long, those on terga 3-4 short; terga $2-3$ with rather short, weak whitish apical fasciae; yellow; caudal fimbria dark brown; sterna with short, sparse brown hairs, sterna $2-5$ without subapical fimbriae.

Structure: Head: HL/HW=0.76. HW: MsW: $M t W=3.8$ : 4.1: 4.3. Vertex roughened above lateral ocelli, smooth and shiny above facial fovea. OOD: POD: $O C D=0.8: 0.5$ : 0.4. FL1= FL2+3, FL2=FL3 as long as broad, following flagellar segments longer than broad. Eyes with inner margins paralleled. Facial fovea broad, extending to

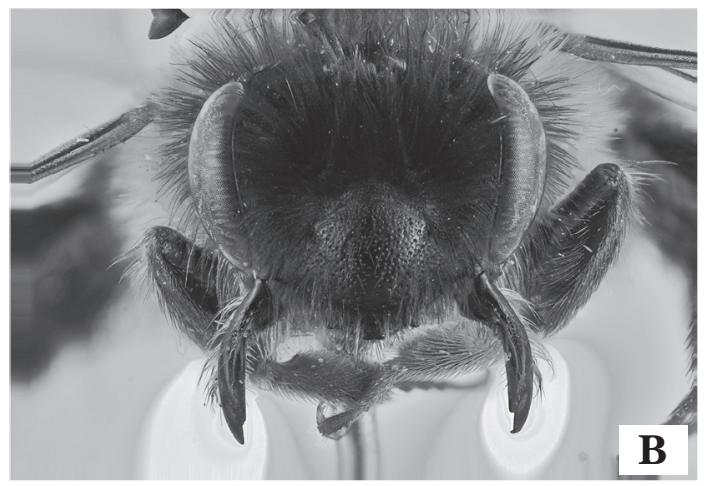


below a line at lower margins of antennal fossae, $\mathrm{FVL}=1.3 \mathrm{~mm}, \mathrm{FVW}=0.5 \mathrm{~mm}$. Supraclypeal area roughened by coarse minute PP. Face above antennal fossae with weak longitudinal rugulae and coarse interrugal PP, surface dull. Facial quadrangle broader than long (about 2.8: 2.5). Clypeus weakly convex, surface weakly tessellate, with median smooth shiny impunctate line, surface finely punctate with $\mathrm{PP} \phi 20 \mu$, IS=0.5-1, sparser at apical margin, $\mathrm{CPL}=1.25 \mathrm{~mm}$. Process of labrum small, trapezoidal, thickened and entire apically, surface tessellate. Labrum apical to process flat, shiny with crista. Lower paraocular area weakly tessellate, shiny with crowded minute PP, hidden by dense hairs. Malar space short, about one-fourth as long as width of basal mandible. Genal area broader than eye, GW: EW=0.9: 0.8, surface weakly tessellate, shiny with close minute PP. Mesosoma: Pronotum with distinct humeral angle and ridge, surface reticularly shagreened. Mesoscutum strongly tessellate, surface shagreened with shallow minute PP, IS=0.5 medially. Scutellum densely tessellate, PP obscured. Propodeum including enclosure densely tessellate all over; dorsal face with weak, sparse minute PP. Mesepisternum densely tessellate, shagreened by minute PP. Vein 1 st $m-c u$ meeting second submarginal cell beyond middle of cell. Metasoma: Metasomal terga densely tessellate, impunctate; posterior depressions of terga narrow, not well indicated; pygidial plate $\mathrm{V}$-shaped with raised internal triangular area. Sterna 2-5 densely tessellate, impunctate.

Male: Unknown.

Type material: Holotype female, Cayu, 3,400-4,200 m, Xizang Autn. Region, China, 12. viii. 1973 (F-s. Huang).

Remarks: This species is similar to Andrena submediocalens $\mathrm{Wu}$ in having the weak white hair bands on the metasomal terga. It is separated from the latter by the larger size, the brown hairs on face of head, the yellow hairs on thorax (brown on submediocalens), the small labral process with entire apex and the propodeal enclosure evenly tessellated.

Distribution: China (Xizang Autn. Region).

Floral association: Not available.

\section{Andrena (Andrena) tumorensis n. sp.}

Andrena infirma (nec Morawitz): Wu, 1876, 1985, Living Things Tianshan Tumorfeng Region Xinjiang, Apoidea, 139 [in list, China].

Female: BL $13.5 \mathrm{~mm}$, WL $10.0 \mathrm{~mm}(\mathrm{n}=1)$.

Color: Flagellum brown beneath; mandible reddened apically; wing membranes subhyaline, moderately brown, veins and pterostigma reddish brown; tibial spurs reddish yellow, posterior margins of metasomal terga reddish yellow subhyaline.

Pubescence: Hairs on head dense, bright brown to brown; those on clypeus $500 \mu$, sparse; those on vertex about $600 \mu$; those on genal area 600-700 $\mu$; facial fovea brown. Hairs on thorax rather dense, uniformly yellow; those on mesoscutum and scutellum $800 \mu$; those on mesepisternum 1,000 $\mu$; propodeal corbicula well devel- oped; trochanteral floccus perfect, yellowish; femoral floccus dense, brown; tibial scopal hairs long, simple, black. Hairs on metasomal terga sparse, brown except terga 1-2 with yellow hairs; caudal fimbria bright brown; sterna with short, sparse, brown hairs; sterna $2-5$ without subapical fimbriae.

Structure: Head: HL/HW =0.86. HW: MsW: MtW=3.5: 3.5: 3.8. Vertex dulled above lateral ocelli, finely tessellate above facial fovea. OOD: POD: $\mathrm{OCD}=0.7$ : 0.5: 0.3 . FL1= FL2+3, FL2=FL3 longer than broad, following flagellar segments longer than broad. Eyes with inner margins slightly diverging toward mandibles. Facial fovea broad, extending to below a line at lower margins of antennal fossae, $\mathrm{FVL}=1.2 \mathrm{~mm}, \quad \mathrm{FVW}=0.5 \mathrm{~mm}$. Supraclypeal area with weak rugulae. Face above antennal fossae with weak longitudinal rugulae and interrugal PP, surface shagreened. Facial quadrangle broader than long (about 2.6: 2.4). Clypeus weakly convex, densely tessellate basally and laterally, weakly tessellate medioapically, shiny with close PP $\phi 20-40 \mu$, IS=0.5, large and sparser PP at apical margin, with median smooth impunctate space, $\mathrm{CPL}=1.2 \mathrm{~mm}$. Process of labrum large, trapezoidal, weakly emarginate apically. Labrum apical to process with crista. Lower paraocular area weakly tessellate, shiny with PP $\phi 20 \mu$, IS $<1$. Malar space about onethird time as long as width of basal mandible. Genal area broader than eye, GW: EW=1.0: 0.8, surface densely tessellate posteriorly, narrowly smooth and shiny with minute PP near eye. Mesosoma: Pronotum with distinct humeral angle and ridge, surface densely tessellate. Mesoscutum strongly tessellate, opaque, PP obscured. Scutellum as in mesoscutum but feebly shiny anteriorly. Propodeal enclosure not well defined, densely tessellate, weakly roughened at basal margin; dorsal face densely tessellate with weak, close PP, surface shagreened. Vein 1st $m-c u$ meeting second submarginal cell near end of cell. Metasoma: Metasomal terga finely tessellate, narrowly shiny, basal areas with scattered weak minute PP; posterior depressions of terga broad, not well indicated; pygidial plate $\mathrm{V}$-shaped with rounded apex, with internal large raised triangular area. Sterna 2-5 weakly tessellate, shiny, impunctate at basal halves, weakly punctate at apical halves.

Type material: Holotype female, Mt. Tumorfeng, Xinjiang Uygur Autn. Region, China, 2,400 m, 22. vi. 1977 (Y-h. Han).

Remarks: This species is similar to Andrena infirma Morawitz in appearance, but infrima belongs to the subgenus Melandrena (Gusenleitner and Schwarz, 2002). This species is recognized by the brown hairs on head, the yellow hairs on thorax, the black tibial scopal hairs, the clypeus with irregular impunctate line and the process of labrum large, emarginate apically.

Distribution: China (Xinjiang Uygur Autn. Region).

Floral association: Not available.

\section{Andrena (Andrena) ishiharai Hirashima}

Andrena (Andrena) ishiharai Hirashima, 1953, Trans. Shikoku ent. Soc., 3: 33 [female, Japan]; Hirashima, 
1962, J. Fac. Agr., Kyushu Univ., 12: 132 [female \& male]; Hirashima, 1966, J. Fac. Agr., Kyushu Univ., 12: 101, 116 [female \& male, in key]; Tadauchi et al., 1987, J. Fac. Agr., Kyushu Univ., 31: 23-24; Tadauchi and Lee, 1992, Esakia, (32): 48 [Korea]; Osytshnjuk, 1995, Key Insects Russian Far East, Vol. IV, Part 1, 514, 522 [female \& male, in key]; Gusenleitner and Schwarz, 2002, Entomofauna, 12(suppl.): 3733-374.

Specimen examined: Holotype female (Kyushu Univ.), Omogo, Iyo Pref., Shikoku, Japan, 11. v. 1952 (T. Ishihara).

Distribution: Japan (Hokkaido, Honshu, Shikoku); Korea; Russia (Far East area).

Floral associations: 14 plants were listed by Tadauchi et al. (1987).

\section{Andrena (Andrena) scutellaris Morawitz}

Andrena scutellaris Morawitz, 1880, Bull. Acad. Sci. St. Petersbourg, 26: 364 [female, Mongolia]; Yasumatsu, 1941, Peking nat. Hist. Bull., 15: 280 [in list].

Andrena (Andrena) scutellaris: Xu and Tadauchi, 1997, J. Fac. Agr., Kyushu Univ., 41: 165-166 [redescription]; Gusenleitner and Schwarz, 2002, Entomofauna, 12(suppl.): 675.

Male (new to science): BL 9.0-9.5 mm, WL 8.5$8.7 \mathrm{~mm}(\mathrm{n}=2)$.

Color: Flagellum blackish beneath; mandible reddened apically; wing membranes subhyaline, veins and pterostigma dark reddish brown; tibial spurs testaceous; posterior margins of metasomal terga dark brown.

Pubescence: Hairs on head long, dense, mainly black; those on clypeus about $700 \mu$; those on antennal area admixed with whitish; those on vertex 700-900 $\mu$, white; those on genal area black. Hairs on mesoscutum and scutellum 500-800 $\mu$; sparse, white mixed with black; those on metanotum white; those on propodeum and mesepisternum black; trochanter and femora with black hairs. Hairs on metasomal terga 1-2 moderately long, white; those on terga 3-5 short, black, white laterally; sterna $2-5$ with short, complete blackish subapical fimbriae.

Structure: Head: HL/HW=0.73. HW: $\mathrm{MsW}: \mathrm{MtW}=3.2$ : 2.5: 2.7. Vertex short, densely tessellate. OOD: POD: $\mathrm{OCD}=0.7:$ 0.4: 0.25. FL1 short, FL2 and following segments distinctly longer than broad. Eyes with inner margins paralleled. Supraclypeal area dulled by minute PP. Face above antennal fossae with fine longitudinal rugulae and weak interrugal PP. Facial quadrangle broader than long (about 2.4: 2.0). Clypeus nearly flattened, densely tessellate laterally, weakly tessellate medioapically, shiny with close $\operatorname{PP} \phi 20 \mu$, IS $<0.5$, without median impunctate line, $\mathrm{CPL}=1.0 \mathrm{~mm}$. Process of labrum small, trapezoidal, deeply emarginate apically. Labrum apical to process flat, with median cristae. Mandibles long, decussate, without basal angle. Lower paraocular area as in clypeus, but PP smaller. Malar space about one-third time as long as width of basal mandible. Genal area angulate posteromedially, GW:
$\mathrm{EW}=0.9$ : 0.7 , surface weakly tessellate posteriorly with small PP, IS=1.5-2, narrowly smooth and shiny with minute PP near eye. Mesosoma: Pronotum with sharp humeral angle and ridge, surface reticularly shagreened. Mesoscutum densely tessellate marginally, finely tessellate medially with small $\operatorname{PP} \phi 15 \mu, \mathrm{IS}=1$. Scutellum densely tessellate posteriorly, smooth and shiny anteriorly with minute PP, IS=1-3. Propodeal enclosure small, rugulate basally, broadly tessellate apically, feebly shiny; dorsal face roughened by coarse tessellation. Mesepisternum weakly shagreened with weak small PP. Vein 1st $m-c u$ meeting second submarginal cell beyond middle of cell. Metasoma: Metasomal terga nearly smooth and shiny, surface scattered minute PP, IS=3 or more; posterior depressions of terga not well indicated. Sterna sculptured as in terga, shiny; sternum 6 flat, not emarginate.

Specimens examined: China, Gansu Province: 4 females and 2 males, Huashai, Zhangye, 2. v. 1996 (S. Ikudome).

Remarks: This species is similar to Andrena subhondoica n. sp. The both sexes are separated from those of subhondoica by the larger size, the emarginated labral process, the smooth propodeal enclosure, the black tibial scopal hairs and the weakly punctate metasomal terga.

Distribution: China (new record, Gansu Prov.); Mongolia.

Floral association: Prunus sp.

\section{Andrena (Andrena) beneficalla n. sp.}

(Fig. 2: A-E)

Female: BL 8.0-9.0 mm, WL 6.7-7.2 mm (n=20).

Color: Flagellum brown beneath; mandible with apical third or more reddened; wing membranes hyaline, clear, veins and pterostigma yellow to yellowish brown; tibial spurs yellow; posterior depressions of metasomal terga dark reddish brown.

Pubescence: Hairs on head dense, white to whitish; those on clypeus 300-400 $\mu$, white; those on vertex about $400 \mu$, whitish, occasionally mixed with brown; those on genal area white; facial fovea brown. Hairs on mesoscutum 300-600 $\mu$, not dense, pale; those on scutellum scanty; those on mesepisternum 600-700 $\mu$, white; propodeal corbicula well developed, white, without internal hairs mostly; trochanteral floccus perfect, white; femoral floccus dense; tibial scopal hairs moderately long, simple, whitish. Hairs on metasomal terga dense, white; those on terga 1-2 (500-600 $\mu$ ), those on terga 3-4 short $(200 \mu)$, terga $2-4$ with short, complete white apical fasciae; caudal fimbria yellow intermixed with white hairs; sterna 2-5 with incomplete white subapical fimbriae.

Structure: Head: HL/HW=0.80. HW: MsW: MtW=2.7: 2.5: 2.7. Vertex short, densely tessellate, surface shagreened. OOD: POD: $\mathrm{OCD}=0.5:$ 0.3: 0.15. FL1=FL2+3, FL2=FL3 broader than long, intermediate flagellar segments as long as broad. Eyes with inner margins paralleled. Facial fovea far exceeding below a line at lower margins of antennal fossae, $\mathrm{FVL}=1.3 \mathrm{~mm}, \mathrm{FVW}=0.4 \mathrm{~mm}$. Supraclypeal area dulled by coarse minute PP. Face 

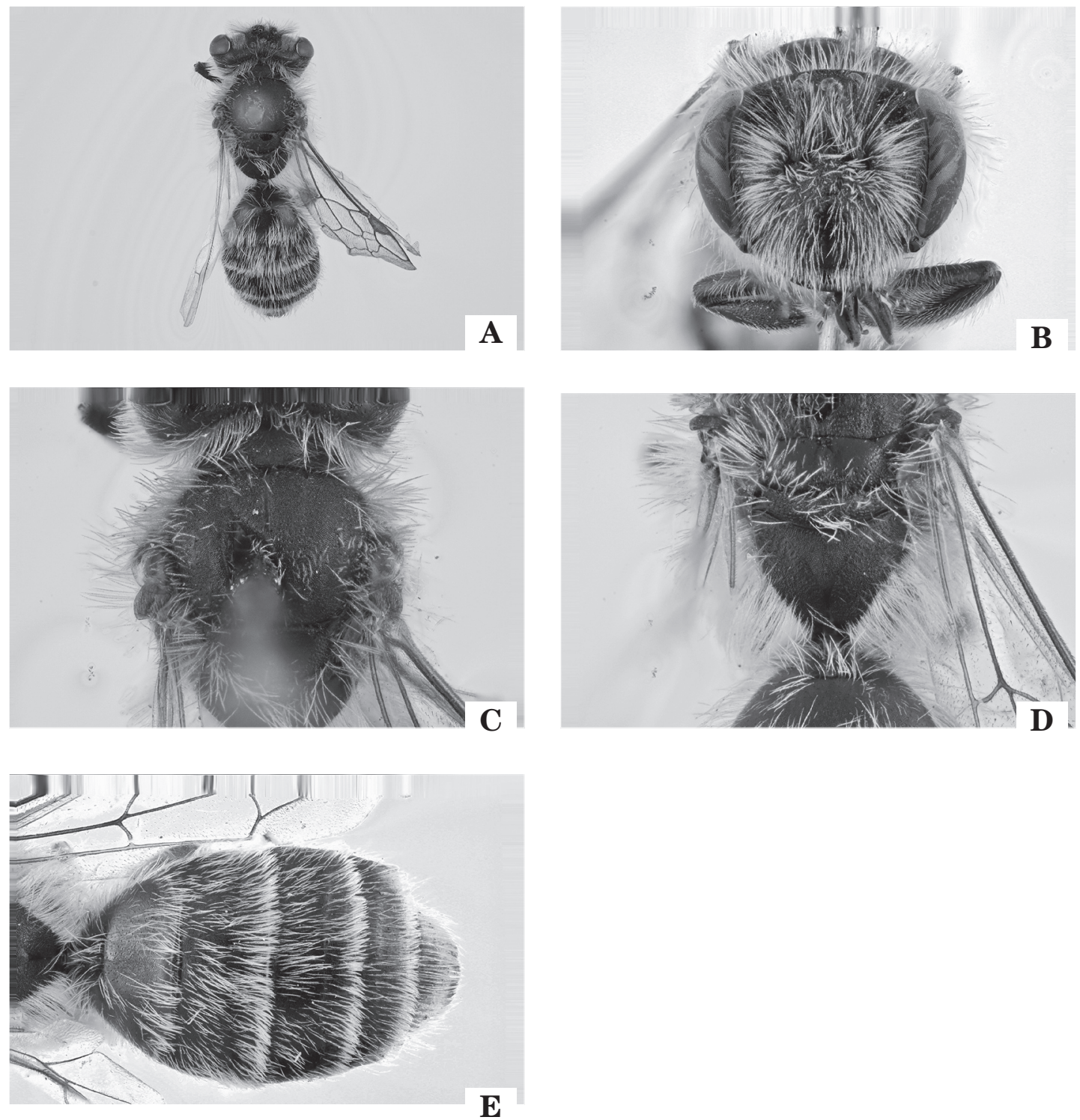

Fig. 2. Andrena (Andrena) beneficalla, n. sp., female. A: general habitus in dorsal view; B: head in frontal view; C: mesoscutum; D: propodeum; E: metasomal terga.

above antennal fossae with longitudinal rugulae and interrugal PP, surface shagreened. Facial quadrangle broader than long (about 2.0: 1.8). Clypeus weakly convex, surface finely tessellate, weakly shiny with crowded PP $\phi 10-30 \mu$, IS $<0.5$, large PP near median line, with median shiny impunctate space, $\mathrm{CPL}=0.8 \mathrm{~mm}$. Process of labrum small, trapezoidal, entire apically. Labrum apical to process without cristae. Lower paraocular area crowdedly punctate. Malar space linear. Genal area as broad as eye, GW: EW=0.6: 0.6, surface finely tessellate, shiny with minute PP near eye. Mesosoma: Pronotum with distinct humeral angle and ridge, surface strongly reticularly shagreened, opaque. Mesoscutum densely tessellate, PP obscured. Scutellum densely tessellate posteriorly, shiny anteriorly with weak PP. Propodeal enclosure well defined, finely granulate all over; dorsal face of propodeum and mesepisternum densely tessellate. Vein 1st $m-c u$ meeting second submarginal cell at or beyond middle of cell. Metasoma: Metasomal tergum 1 densely tessellate; terga 2-4 finely tessellate, feebly shiny, impunctate; posterior depression of tergum 2 narrow, depressions of terga 3-4 broad, occupied half or more length of tergal segments, well indicated; pygidial plate $\mathrm{V}$-shaped with rounded apex, with internal raised triangular area. Sterna 2-5 finely tessellate with close minute PP.

Male: BL 6.5-7.5 mm, WL 6.0-7.0 mm $(\mathrm{n}=20)$.

Color: Flagellum dark brown beneath; mandible reddened apically; wing membranes subhyaline, veins and pterostigma reddish yellow; tibial spurs yellow, posterior margins of metasomal terga yellowish brown.

Pubescence: Hairs on head and thorax as in female; dense and white on clypeus; propodeal fringes light brown. Hairs on metasomal terga sparser, terga 2-4 with rather short, weak apical fasciae, dull white, broadly interrupted on terga 2-3; sterna 2-5 each with short, complete, subapical fimbriae.

Structure: Head: HL/HW=0.79. HW: MsW: MtW=2.9: 2.0: 2.0. Vertex short, strongly tessellate. OOD: POD: OCD=0.55: 0.3: 0.15. FL1 as long as FL2, FL2 about as 
long as FL3, longer than broad, following segments longer than broad. Eyes with inner margins paralleled. Supraclypeal area shagreened. Face above antennal fossae with weak longitudinal rugulae, surface dull. Facial quadrangle broader than long (about 1.7: 1.5). Clypeus nearly flattened, weakly tessellate, shiny with crowded $\mathrm{PP} \phi 10-15 \mu$, IS $<0.5$, with median narrow impunctate line, $\mathrm{CPL}=0.7 \mathrm{~mm}$. Process of labrum as in female but smaller. Mandibles long, decussate, without basal tooth. Lower paraocular area finely tessellate with crowded minute PP. Malar space linear. Genal area broadened, angulated posteromedially, GW: $\mathrm{EW}=0.8$ : 0.6 , surface finely tessellate, scattered minute PP. Mesosoma: Thoracic form and sculpturing as in female except mesoscutum more tessellate, opaque. Wing venation as in female. Metasoma: Metasomal terga finely tessellate basally, weakly tessellate apically, shiny, nearly impunctate; posterior depressions of terga narrow, not well indicated. Sterna 2-5 weakly tessellate, shiny, weakly punctate near apical areas; sternum 6 flat.

Type material: Holotype female, Subei County, Gansu Province, 9. v. 1996 (H-l. Xu); Paratypes: Gansu Province: same locality and date as the holotype: 30 females and 5 males ( $\mathrm{H}-\mathrm{l}$. Xu), 15 females and 3 males (O. Tadauchi), 108 females and 32 males (S. Ikudome); Ganjun, Zhangye: 1 female (S. Ikudome), 1 male (O. Tadauchi), 1. v. 1996; Wuwei: 3 females (S. Ikudome), 5 females and 1 male (H-l. Xu), 2 females (O. Tadauchi), 29. iv. 1996.

Remarks: This species is similar to Andrena benefica Hirashima in having the evenly granulated propodeal enclosure and the apical fasciae of metasomal terga in female. The female can be separated from that of benefica by the smaller size, the less shiny clypeus with denser PP, the small labral process with apex entire and the more distinct white tergal apical fasciae. The male can be separated from that of benefica by the mandible without basal spine, the smaller labral process and the more shagreened mesoscutum.

Distribution: China (Gansu Prov.).

Floral associations: All specimens were collected on Salix sp. except one female collected on flower of Prunus sp.

\section{Andrena (Andrena) subhondoica n. sp.}

(Fig. 3: A-E)

Female: BL 9.0-11.0 mm, WL 8.5-9.0 mm (n=13).

Color: Flagellum dark brown beneath; mandible reddened apically; wing membranes hyaline, clear, veins and pterostigma reddish brown; tibial spurs yellowish; posterior depressions of metasomal terga dark reddish brown.

Pubescence: Hairs on head more or less dense, dull yellow mixed with black on face; those on clypeus 400$500 \mu$, dull yellow; those on vertex about $600 \mu$, dull yellow with short sparse brown; those on genal area sparse, whitish; facial fovea brown above, whitish below. Hairs on mesoscutum and scutellum 500-700 $\mu$, pale white to dirty yellow; those on mesepisternum 700-1,200 $\mu$, paler; propodeal corbicula well developed, white, without inter- nal hairs mostly; trochanteral floccus perfect, whitish; femoral floccus dense; tibial scopal hairs moderately long, simple, whitish to light brown; basitarsi with brown hairs. Hairs on metasomal terga sparse, erect, whitish; those on terga 1-2 long, those on terga 3-4 relatively short, terga $2-4$ with short, weak white apical fasciae; caudal fimbria light brown; sterna $2-5$ with short, complete whitish subapical fimbriae.

Structure: Head: HL/HW=0.78. HW: MsW: $\mathrm{MtW}=3.2: 2.9: 3.2$. vertex short, roughened. OOD: POD: $\mathrm{OCD}=0.6: 0.4: 0.14$. FL1 slightly longer than or subequal to FL2+3, FL2=FL3 as broad as long, intermediate flagellar segments as long as broad. Eyes with inner margins subparalleled. Facial fovea far exceeding below a line at lower margins of antennal fossae, close to eye, FVL=1.4 mm, FVW=0.5 mm. Supraclypeal area dulled by coarse minute PP. Face above antennal fossae with distinct close longitudinal rugulae and interrugal PP, surface shagreened. Facial quadrangle broader than long (about 2.4:2.1). Clypeus weakly convex, surface finely tessellate, with $\operatorname{PP} \phi 20 \mu$, IS $=1$, smaller and denser at extreme angle area, with median narrow impunctate space, $\mathrm{CPL}=1.0 \mathrm{~mm}$. Process of labrum trapezoidal with rounded entire apex. Labrum apical to process with weak cristae. Lower paraocular area coarsely tessellate. Malar space nearly linear. Genal area broader than eye, GW: $E W=0.8$ : 0.7 , surface finely tessellate with close minute PP. Mesosoma: Pronotum with humeral angle and ridge, surface reticularly shagreened. Mesoscutum strongly tessellate, opaque. Scutellum densely tessellate posteriorly, weakly tessellate to smooth and shiny anteriorly with weak $\mathrm{PP} \phi 20 \mu$, IS $<1$. Propodeal enclosure large, weakly rugulose basally, densely tessellate apically, opaque; dorsal face of propodeum roughened by coarse tessellation. Mesepisternum strongly tessellate, roughened. Vein 1st $m-c u$ meeting second submarginal cell near end of cell. Metasoma: Metasomal tergum 1 finely tessellate, narrowly shiny, impunctate or occasionally scattered microscopic PP; terga 2-4 weakly tessellate, shiny, impunctate; posterior depressions of terga not well indicated; pygidial plate V-shaped, with internal raised triangular area. Sterna 2-5 weakly tessellate, shiny, impunctate basally, weakly punctate apically.

Male: BL 9.0 mm, WL $8.0 \mathrm{~mm}(\mathrm{n}=1)$.

Color: Flagellum dark brown beneath; mandible reddened apically; wing membranes hyaline, veins and pterostigma yellowish brown; tibial spurs yellowish; posterior margins of metasomal terga reddish yellow.

Pubescence: Hairs on head and thorax white to black; those on clypeus $800 \mu$, rather dense, white; those on antennal area white mixed with black; those on face along inner margins of eye brown; those on vertex $700 \mu$, dull white; those on genal area brown above, whitish below; those on mesoscutum and scutellum 700-800 $\mu$, dull white; those on mesepisternum long, whitish; those on propodeum dark brown; legs with long white hairs, but inner surface of basitarsi with yellow ones. Hairs on metasomal terga sparser, dull white; those on tergum 1 and basal tergum 2 long; those on terga 3-5 short; terga 3-4 with incomplete, very weak apical fasciae; sterna $2-5$ 

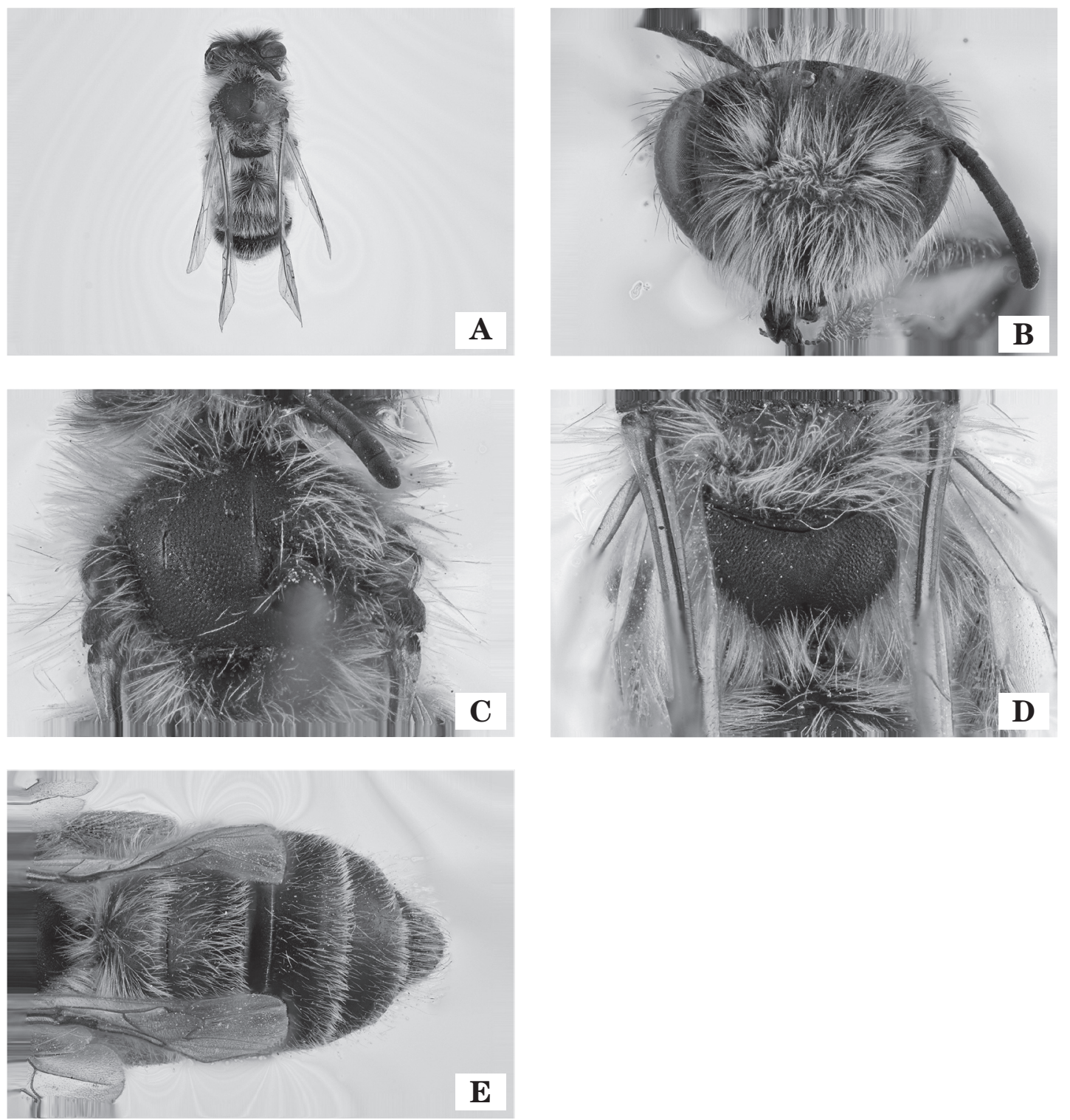

Fig. 3. Andrena (Andrena) subhondoica, n. sp., female. A: general habitus in dorsal view; B: head in frontal view; C: mesoscutum; D: propodeum; E: metasomal terga.

each with short, complete, subapical fimbria, whitish.

Structure: Head: HL/HW=0.75. HW: MsW: MtW=3.0: 2.5: 2.7. Vertex short, tessellate, dulled above lateral ocelli. OOD: POD: $\mathrm{OCD}=0.7$ : 0.5: 0.2. FL1 twice as long as FL2, FL2 shorter than FL3, following segments longer than broad. Eyes with inner margins paralleled. Supraclypeal area dulled by coarse small PP. Face above antennal fossae with weak longitudinal rugulae, surface shagreened. Facial quadrangle broader than long (about 2.2: 2.0). Clypeus nearly flattened, finely tessellate, surface dulled by crowded minute PP, without median impunctate line, $\mathrm{CPL}=0.9 \mathrm{~mm}$. Process of labrum small, trapezoidal, entire apically. Mandibles long, decussate, without basal spine. Lower paraocular area finely tessellate with close minute PP. Malar space nearly linear. Genal area angulated posteromedially, GW: $\mathrm{EW}=0.9$ : 0.7, surface finely tessellate with minute $\mathrm{PP}$, IS=1 or more. Mesosoma: Thoracic form and sculpturing as in female. Metasoma: Metasomal terga weakly tessellate, shiny, sur- face with scattered weak minute PP; posterior depressions of terga narrow, not well indicated. Sterna 2-5 sculptured as in terga, but PP closer at apical areas; sternum 6 flat.

Type material: Holotype female: Ganjun, Zhangye, Gansu Province, China, 1. v. 1996 (O. Tadauchi); Paratypes: Gansu Province: same data as the holotype: 1 female (H-l. Xu); 1 male (O. Tadauchi); Wuwei: 1 female (H-l. Xu); 1 female (O. Tadauchi); 2 females (S. Ikudome), 29. iv. 1996; Jiuquan: 2 females (H-l. Xu); 8 females (S. Ikudome); 5. v. 1996. Heilongjiang Province: 1 female, Harbin, 16. v. 1954.

Remarks: This species is similar to Andrena hondoica Hirashima in appearance. The female can be separated from that of hondoica by the more densely punctated clypeus, the weakly tessellate to smooth and shiny scutellum with distinct PP and the less rugulated propodeal enclosure at base. The male can be separated from 
that of hondoica by the mandible without basal angle and the same features as in female.

Distribution: China (Gansu, Heilongjiang Provs.).

Floral association: Salix sp.

\section{Andrena (Andrena) hondoica Hirashima}

Andrena (Andrena) hondoica Hirashima, 1962, J. Fac.

Agr., Kyushu Univ., 12: 144 [female \& male, Japan]; Hirashima, 1966, J. Fac. Agr., Kyushu Univ., 12: 103104 [female in key]; Tadauchi et al., 1987, J. Fac. Agr., Kyushu Univ., 31: 37-38; Osytshnjuk, 1995, Key Insects Russian Far East, Vol. IV, Part 1, 516, 522 [female \& male, in key]; Gusenleitner and Schwarz, 2002, Entomofauna, 12(suppl.): 348-349.

Specimens examined: Holotype male and allotype female (Kyushu Univ.).

Distribution: Japan (Hokkaido, Honshu); Russia (Far East Area).

Floral association: See Tadauchi et al. (1987).
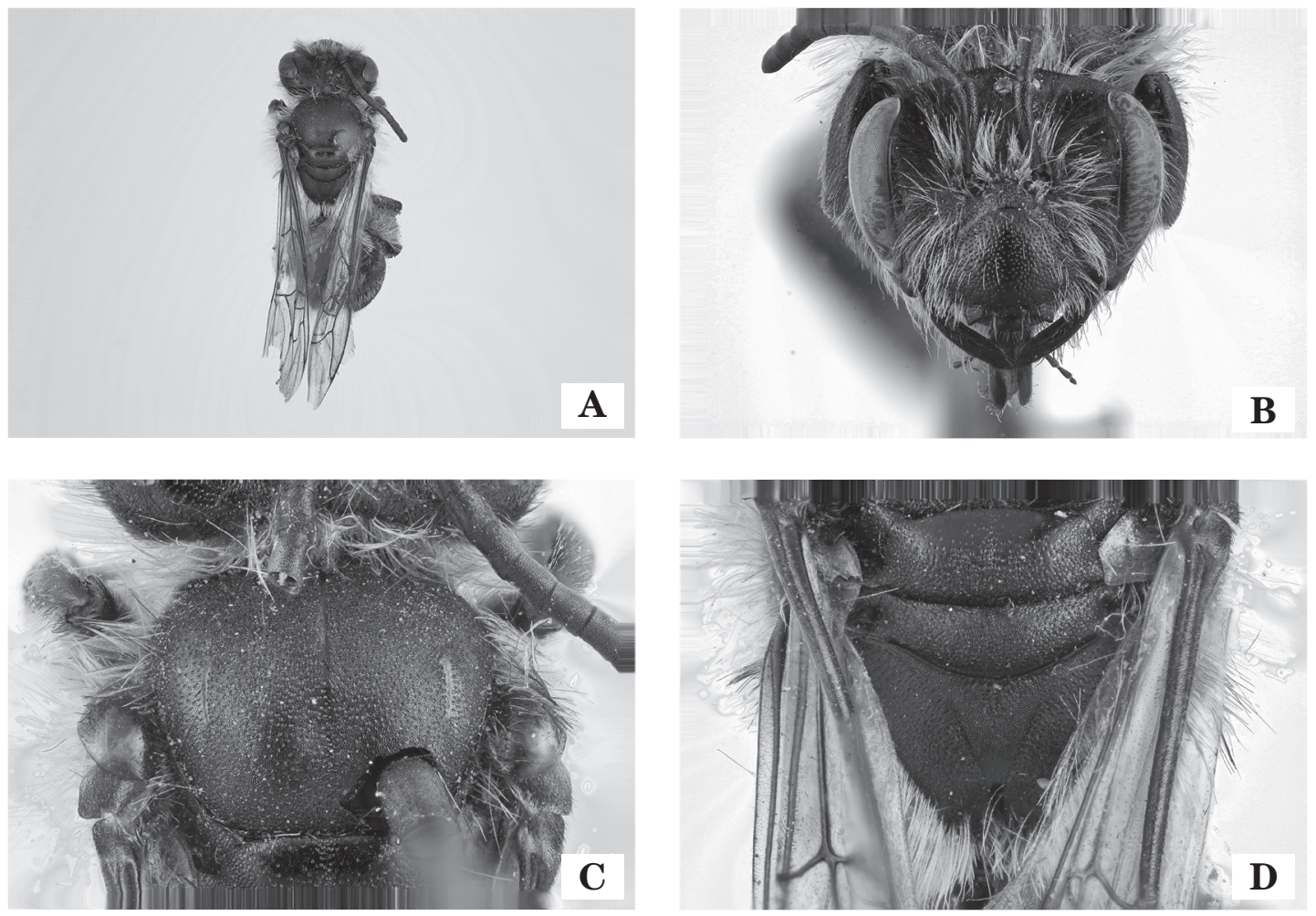

\section{Andrena (Andrena) maerkangensis n. sp.}

(Fig. 4: A-E)

Female: BL $13.0 \mathrm{~mm}$, WL $11.0 \mathrm{~mm}(\mathrm{n}=1)$.

Color: Flagellum dark reddish brown beneath; mandible reddened apically, wing membranes hyaline, clear, veins and pterostigma reddish brown; middle basitarsi and hind tibiae and basitarsi reddish, tibial spurs testaceous, posterior margins of metasomal terga yellowish brown subhyaline.

Pubescence: Hairs on head sparse, mainly pale white; antennal area and vertex mixed with brown ones; those on clypeus 200-400 $\mu$, scanty medially; those on vertex about $500 \mu$; facial fovea black. Hairs on mesoscutum and scutellum 400-600 $\mu$, black; those on pronotal lobe and mesepisternum whitish; propodeal corbicula completely developed, dull white mixed with black, without internal hairs; trochanteral floccus perfect, white; femoral floccus dense; tibial scopal hairs long, simple, golden yellow. Hairs on metasomal terga not so dense, whitish; those on terga 1-2 long, those on terga 3-4 short, apical

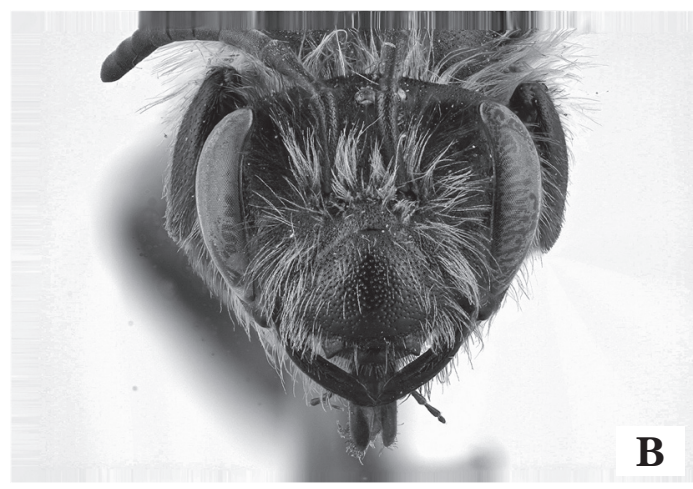

B

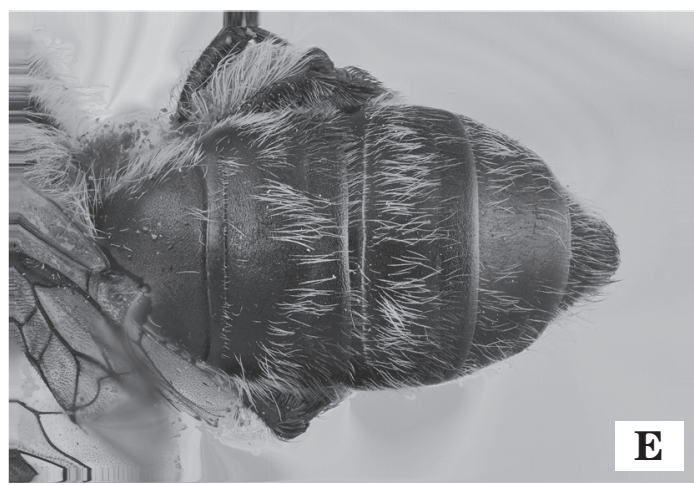

Fig. 4. Andrena (Andrena) maerkangensis, n. sp., female. A: general habitus in dorsal view; B: head in frontal view; C: mesoscutum; D: propodeum; E: metasomal terga. 
margins without hair bands; caudal fimbria light brown; sterna 2-5 with weak, whitish subapical fimbriae.

Structure: Head: HL/HW=0.76. HW: MsW: $\mathrm{MtW}=3.6$ : 3.5: 3.5. Vertex densely tessellate. OOD: POD: $\mathrm{OCD}=0.75: 0.45: 0.25$. FL1=FL2+3, FL2=FL3 longer than broad, following flagellar segments longer than broad. Eyes with inner margins subparalleled. Facial fovea extending to below a line at lower margins of antennal fossae, $\mathrm{FVL}=1.3 \mathrm{~mm}, \mathrm{FVW}=0.5 \mathrm{~mm}$, narrowing toward below. Supraclypeal area dulled by dense minute PP. Face above antennal fossae with weak longitudinal rugulae and coarse interrugal PP, surface dull. Facial quadrangle broader than long (about 2.6: 2.4). Clypeus weakly convex, surface finely tessellate basally and laterally, smooth and shiny medioapically with $\operatorname{PP} \phi 20 \mu$, $\mathrm{IS}=0.5$, apical margin scattered with weak PP, with median indistinct longitudinal impunctate line, $\mathrm{CPL}=1.2 \mathrm{~mm}$. Process of labrum moderate, emarginate apically. Labrum apical to process flat, smooth and shiny, with median crista. Lower paraocular area finely tessellate, moderately dulled by close PP. Malar space distinct, about one-third as long as width of basal mandible. Genal area broader than eye, GW: $\mathrm{EW}=1.0$ : 0.8, surface weakly tessellate, shiny with weak minute PP, IS=1.5-2. Mesosoma: Pronotum with weak humeral angle and ridge. Mesoscutum densely tessellate, weakly punctate medially with obscure minute PP. Scutellum as in mesoscutum, but shiner anteriorly. Propodeal enclosure finely granulate all over, well defined by lateral ridges; dorsal face of propodeum densely tessellate, minutely punctate. Mesepisternum densely tessellate with obscure PP. Vein 1 st $m-c u$ meeting second submarginal cell at basal two-thirds of cell. Metasoma: Metasomal terga densely tessellate, impunctate; posterior depressions of terga well indicated; pygidial plate V-shaped with raised internal triangular area. Sterna 2-5 weakly tessellate, shiny, impunctate basally, weakly punctate apically.

Male: Unknown.

Type material: Holotype female: Maerkang, 2,500 m, Sichuan Province, China, 20. viii. 1983 (R-q, Wang).

Remarks: This species is described based on one female. The female is similar to Andrena pseudocineraria $\mathrm{Wu}$, but can be separated from the latter by the deep punctures on clypeus, the less black hairs on thorax, the tibial scopal hairs white and the metasomal terga impunctate.

Distribution: China (Sichuan Prov.).

Floral association: Not available.

17. Andrena (Andrena) saragamineensis Hirashima Andrena (Andrena) saragamineensis Hirashima, 1962, J. Fac. Agr., Kyushu Univ., 12: 149 [female \& male, Japan]; Hirashima, 1966, J. Fac. Agr., Kyushu Univ., 12: 104, 115 [female \& male, in key]; Tadauchi et al., 1987, J. Fac. Agr., Kyushu Univ., 31: 28-29; Gusenleitner and Schwarz, 2002, Entomofauna, 12(suppl.): 695-660.

Specimens examined: Holotype male and allotype female (Kyushu Univ.), Mt. Saragamine, Ehime Pref., Shikoku, Japan, 16. iv. 1952 (T. Ishihara).

Distribution: Japan (central Honshu, Shikoku).

Floral association: Not available.

\section{Andrena (Andrena) cristatolabra n. sp.}

(Fig. 5: A-E)

Female: BL 10.0-11.0 mm, WL 8.5-8.8 mm (n=2).

Color: Flagellum ferruginous beneath except at base; mandible with apical third reddened; wing membranes yellowish brown, veins and pterostigma reddish brown; tibial spurs yellow, posterior margins of metasomal terga dark reddish brown.

Pubescence: Hairs on head dense, yellowish to reddish brown; those on clypeus 300-400 $\mu$; those on antennal area yellowish mixed with brown; those on vertex about 300-500 $\mu$, reddish brown; those on genal area yellowish white; facial fovea brown. Hairs on thorax dense, pale yellow; those on mesoscutum and scutellum 500-700 $\mu$; those on mesepisternum about $700 \mu$, paler; propodeal corbicula well developed, yellowish white; trochanteral floccus perfect, white; femoral floccus dense; tibial scopal hairs long, simple, yellowish brown. Hairs on metasomal terga dense, decumbent, yellow intermixed with brown; those on terga 1-2 long, yellow; terga 3-4 with short, brown hairs on basal areas, whitish on apical areas; those on tergum 5 and caudal fimbria brown; sterna $2-5$ with sparse, incomplete yellowish subapical fimbriae.

Structure: Head: HL/HW =0.81. HW: MsW: MtW=3.1: 2.9: 3.2. Vertex roughened by coarse tessellation and punctation. OOD: POD: $\mathrm{OCD}=0.6: 0.4: 0.3$. FL1=FL2+3, FL2=FL3 as long as broad, intermediate flagellar segments about as long as broad. Eyes with inner margins paralleled. Facial fovea short, not extending to below a line at lower margins of antennal fossae, separated from eye by narrow polished space, $\mathrm{FVL}=0.9 \mathrm{~mm}$, FVW=0.3 mm. Supraclypeal area shagreened by fine minute PP. Face above antennal fossae with close longitudinal rugulae and coarse interrugal PP, surface dull. Facial quadrangle broader than long (about 2.2: 2.0). Clypeus weakly convex, surface densely tessellate basally and laterally, finely tessellate medially with $\mathrm{PP} \phi 20$ $30 \mu$, IS $=0.5-1$, large PP near median line, with median indistinct impunctate line, $\mathrm{CPL}=1.0 \mathrm{~mm}$. Process of labrum trapezoidal, bidentate apically. Labrum apical to process flat, smooth and shiny with distinct laminate cristae. Lower paraocular area weakly tessellate, shiny with fine PP, hidden by dense hairs. Malar space rather short, about one-fifth as long as width of basal mandible. Genal area broader than eye, GW: $\mathrm{EW}=0.9$ : 0.7, surface weakly tessellate posteriorly, smooth and shiny with close minute PP near eye. Mesosoma: Pronotum with humeral angle and weak ridge, surface reticularly shagreened with weak PP. Mesoscutum densely tessellate, opaque, PP obscured. Scutellum densely tessellate posteriorly, weakly tessellate anteriorly, shiny with weak minute PP. Propodeal enclosure small, densely tessellate, not well defined; dorsal face of propodeum strongly shagreened. Mesepisternum densely tessellate, not 
roughened. Middle basitarsi broader than hind ones as in Cnemidandrena. Vein 1 st $m-c u$ meeting second submarginal cell at middle of cell. Metasoma: Metasomal terga 1-2 densely tessellate, impunctate; terga 3-4 finely tessellate with minute PP, obscured by dense hairs; posterior depressions of terga not well indicated; pygidial plate V-shaped with rounded apex, with internal large raised triangular area. Sterna 2-5 weakly tessellate, shiny, impunctate at basal halves, sparsely punctate at apical halves.

Male: BL $8.5 \mathrm{~mm}$, WL $7.0 \mathrm{~mm}(\mathrm{n}=1)$.

Color: Flagellum ferruginous beneath except at base; mandible with apical third more reddened; wing membranes subhyaline, moderately brown, veins and pterostigma reddish brown; tibial spurs yellow, posterior margins of metasomal terga yellowish subhyaline.

Pubescence: Hairs on head dense, yellow intermixed with brown; those on clypeus 600-700 $\mu$, rather dense, yellow; those on antennal area yellow mixed with brown; those on vertex 400-700 $\mu$, yellowish brown; those on genal area pale yellow. Hairs on thorax long, dense, reddish yellow, paler laterally. Hairs on metasomal terga dense, yellow, decumbent; those on terga 1-2 long, those on terga $3-5$ short, apical margins of terga $3-5$ with yellowish white fasciae; sterna with dense yellow hairs, sterna 2-5 with weak, not well-formed subapical fimbriae.

Structure: Head: HL/HW=0.77. HW: MsW: MtW=3.0: 2.1: 2.1. Vertex densely tessellate with fine PP. OOD: POD: $\mathrm{OCD}=0.7$ : 0.35: 0.4. FL1 about as long as FL2+3, following flagellar segments longer than broad. Eyes with inner margins paralleled. Supraclypeal area and face above antennal fossae sculptured as in female. Facial quadrangle broader than long (about 2.2: 1.8). Clypeus flattened, weakly concave medially, smooth and shiny with distinct close PP $\phi 20 \mu$, IS $<0.5$, sparser medioapically, $\mathrm{CPL}=0.8 \mathrm{~mm}$. Process of labrum short, emarginate apically. Mandibles long, decussate, with basal ventral angles. Lower paraocular area smooth and shiny with PP 20, IS $<1$. Malar space short, about one-sixth as long as width of basal mandible. Genal area angulated
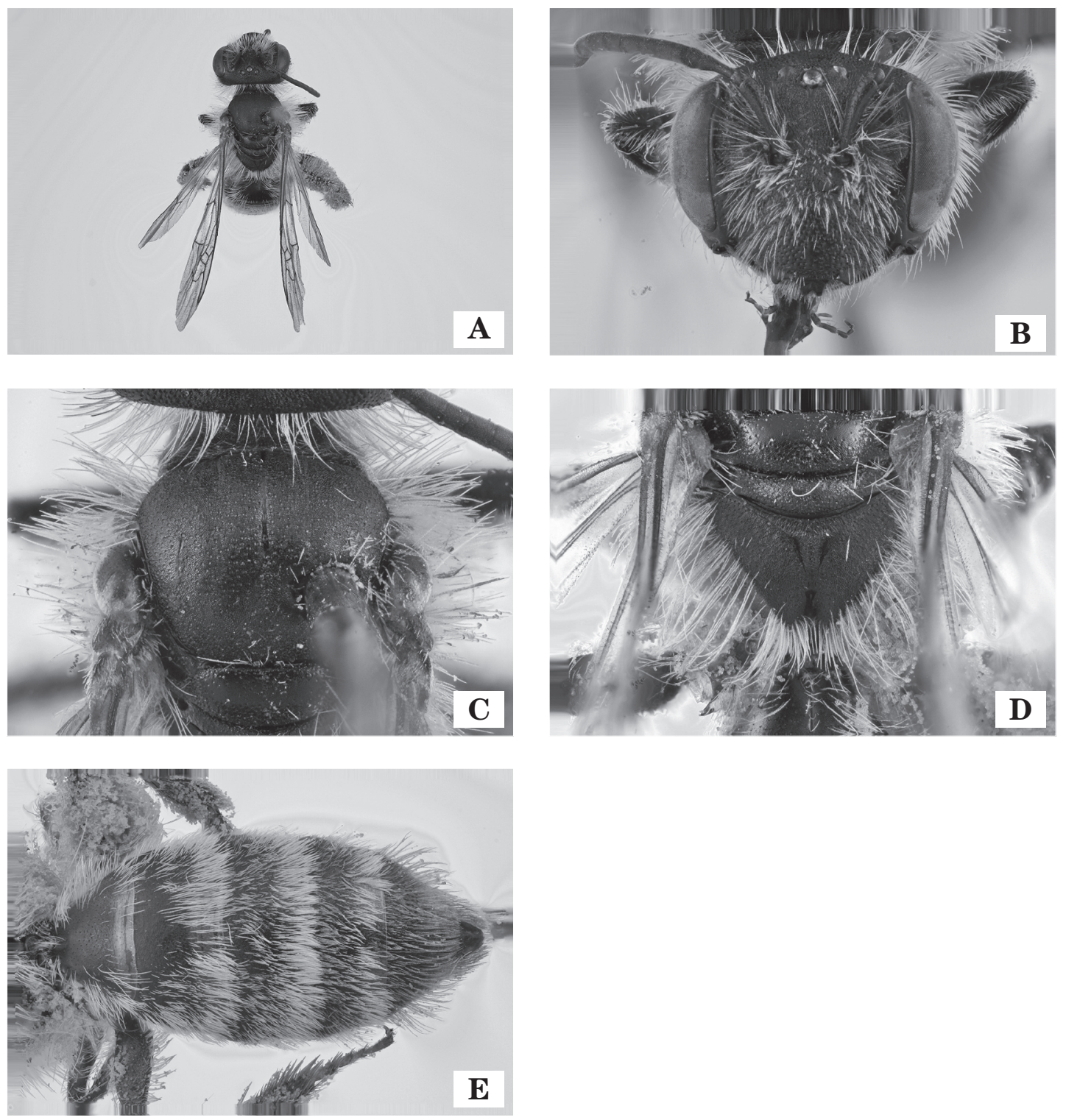

Fig. 5. Andrena (Andrena) cristolabstra, n. sp., female. A: general habitus in dorsal view; B: head in frontal view; C: mesoscutum; D: propodeum; E: metasomal terga. 
posteromedially, GW: EW=1.1: 0.7, surface smooth and shiny, with scattered minute PP posteriorly, close PP near eye. Mesosoma: Pronotum with sharp humeral angle and ridge. Mesoscutum strongly tessellate, surface shagreened. Scutellum densely tessellate posteriorly, smooth and shiny anteriorly with irregular minute PP. Propodeal enclosure densely tessellate with short, weak rugulae basally, lateral margins weakly shiny; dorsal face of propodeum strongly tessellate, shagreened. Mesepisternum finely tessellate, weakly shiny with sparse PP. Vein 1st $m-c u$ meeting second submarginal cell beyond middle of cell. Metasoma: Metasomal terga 1-2 smooth and shiny, scattered weak microscopic PP; terga 3-5 weakly tessellate, shiny with weak, close microscopic $\mathrm{PP}$; posterior depressions of terga narrow, more or less well indicated. Sterna 2-5 finely tessellate, scattered weak PP; sternum 6 well reflected, not emarginate.

Type material: Holotype male, Lanping, 2,350 m, Yunnan Province, China, 25. viii. 1984 (J-g. Fan); Paratypes: 2 females, same locality as the holotype, 24. viii. 1984 (J-g. Fan) and 27. viii. 1984 (R-q. Wang).

Remarks: This species is an unique one in this subgenus. The female is readily recognized by the short facial fovea, the deeply emarginated labral process, the laminated crista below labrum, the small propodeal enclosure anxd the broad apical fasciae on the metasomal terga. The male is recognized by the abundant yellow hairs on the body, the mandible with short basal angle, the long first flagellar segment which is slightly shorter than the next two segments together in length, the metasomal terga with hair bands and the distinctly reflected sternum 6.

Distribution: China (southwest of Yunnan Prov.).

Floral association: Not available.

\section{Andrena (Andrena) mali Tadauchi, Hirashima et Matsumura}

Andrena (Andrena) mali Tadauchi et al., 1987, J. Fac. Agr., Kyushu Univ., 31: 18-20 [female, Japan]; Gusenleitner and Schwarz, 2002, Entomofauna, 12(suppl.): 454.

Specimen examined: Holotype female (Type No. 2579, Kyushu Univ.). Apple Farm, Kuroiso, Tochigi Pref., Japan, 14. v. 1965 (E. Katayama).

Distribution: Japan (central Honshu).

Floral association: Malus pumila.

\section{Andrena (Andrena) benefica Hirashima}

Andrena (Andrena) benefica Hirashima, 1962, J. Fac. Agr., Kyushu Univ., 12: 151-154 [female \& male, Japan]; Hirashima, 1966, J. Fac. Agr., Kyushu Univ., 14: 104, 115 [female \& male, in key]; Tadauchi et al., 1987, J. Fac. Agr., Kyushu Univ., 31: 45-46; Osytshnjuk, 1995, Key Insects Russian Far East, Vol. IV, Part 1, 516, 522 [female \& male, in key]; Tadauchi et al., 1997, Esakia, (37): 188-189 [in list, Korea]; Gusenleitner and Schwarz, 2002, Entomofauna, 12(suppl.): 121.
Specimens examined: Holotype male and allotype female (Kyushu Univ.), Tachibanayama, Fukuoka, Kyushu, Japan, 13-21. iv. 1951 (Y. Hirashima). Other material: China: Heilongjiang Province: 6 females, Jingpo Lake, Mudanjiang, 23-27. v. 1993 (O. Tadauchi); 1 male, Chientao, Mudanjiang, 15. v. 1944 (T. Goto); Harbin: 5 females, 7. v. 1954; 13 females and 8 males, 29. iv. 1954.

Distribution: China (new record, Heilongjiang Prov.); Japan (Hokkaido, Honshu, Sado Is., Shikoku, Kyushu); Korea (southern and central Korea); Russia (Far East Area).

Floral association: China: Taraxacum sp.

\section{Andrena (Andrena) babai Tadauchi, Hirashima et Matsumura}

Andrena (Andrena) babai Tadauchi, Hirashima et Matsumura, 1987, J. Fac. Agr., Kyushu Univ., 31: 47-49 [female \& male, Japan] ; Gusenleitner and Schwarz, 2002, Entomofauna, 12(suppl.): 110.

Specimen examined: Holotype female (Type No. 2574, Kyushu Univ.), Senami, Niigata Pref., Japan, 9. iv. 1985 (K. Baba).

Distribution: Japan (central Honshu, Sado Is.).

Floral association: Salix sp.

\section{Andrena (Andrena) kunmingica n. sp.}

Female: BL $13.5 \mathrm{~mm}$, WL $10.5 \mathrm{~mm}(\mathrm{n}=1)$.

Color: Flagellum dark reddish beneath; mandible with apical half more reddened; wing membranes subhyaline, weakly brown, veins and pterostigma reddish brown; tibial spurs testaceous, posterior margins of metasomal terga yellowish brown subhyaline.

Pubescence: Hairs on head more or less dense, generally yellow but antennal area and vertex brown; those on clypeus 500-750 $\mu$, fulvous; those on vertex about $750 \mu$; those on genal area yellowish; facial fovea dark brown. Hairs on thorax dense, yellow to yellowish white; those on mesoscutum 600-700 $\mu$, black; those on mesepisternum 1,200 $\mu$, yellowish white; propodeal corbicula well developed, anterior fringe not dense, with internal short simple hairs; trochanteral floccus perfect, white; femoral floccus dense; tibial scopal hairs long, simple, black. Hairs on metasomal tergum 1 long, sparse, dull yellowish; those on tergum 2 moderately long basally, terga 3-4 basal margins with rather short dull white hairs, other areas short brown hairs; caudal fimbria dark brown; sterna 2-5 with incomplete white to brown subapical fimbriae.

Structure: head: HL/HW=0.78. HW: MsW: MtW=3.6: 3.8:4.0. Vertex short, densely tessellate. OOD: POD: $\mathrm{OCD}=0.7:$ 0.4: 0.2 . FL1 $=\mathrm{FL} 2+3, \mathrm{FL} 2$ about as long as FL3, distinctly longer than broad, following flagellar segments longer than broad. Eyes with inner margins slightly diverging toward mandibles. Facial fovea deeply concave, broad, extending to below a line at lower margins of antennal fossae, $\mathrm{FVL}=1.5 \mathrm{~mm}, \mathrm{FVW}=0.6 \mathrm{~mm}$. Supraclypeal area dulled. Face above antennal fossae with longitudinal rugulae and obscure interrugal PP. Facial quadrangle as broad as long (about 2.4: 2.4). 

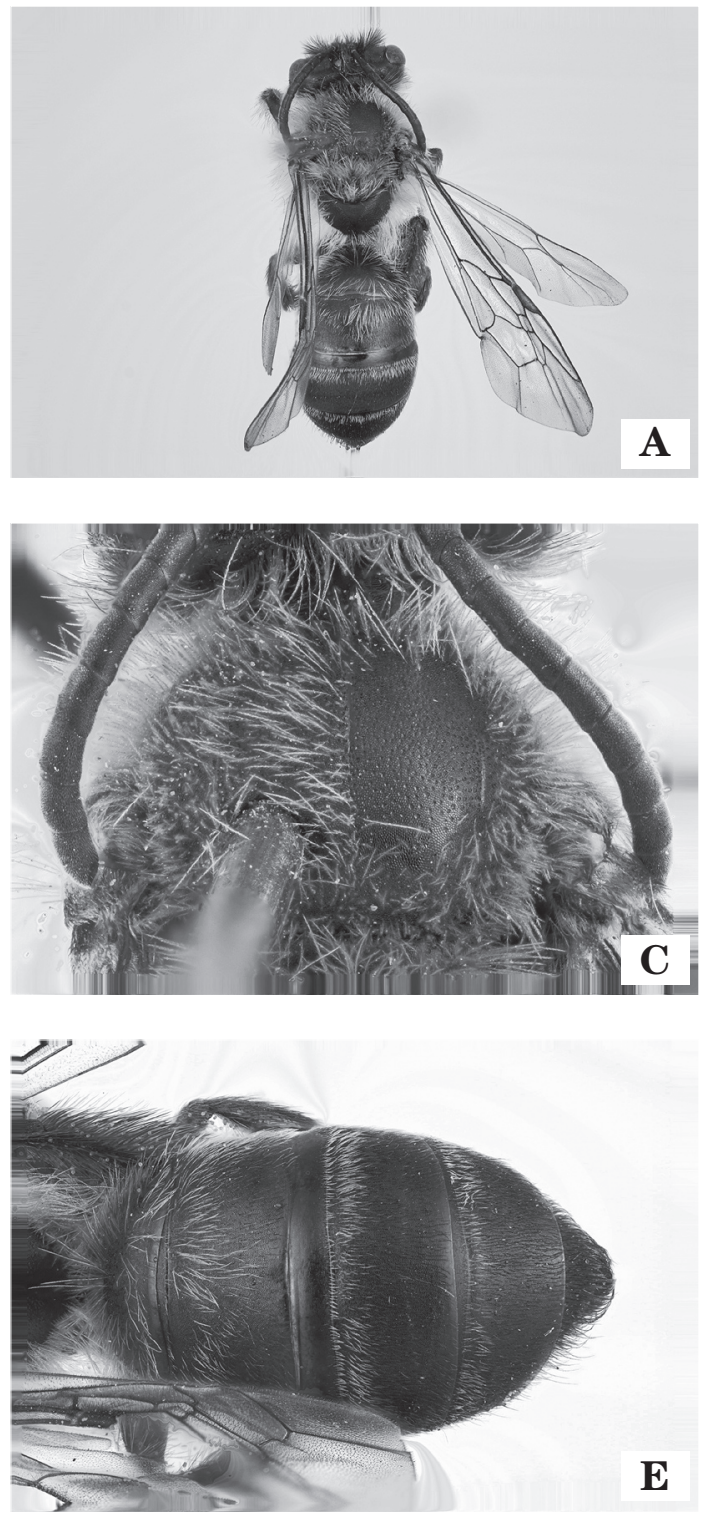

$\mathbf{E}$
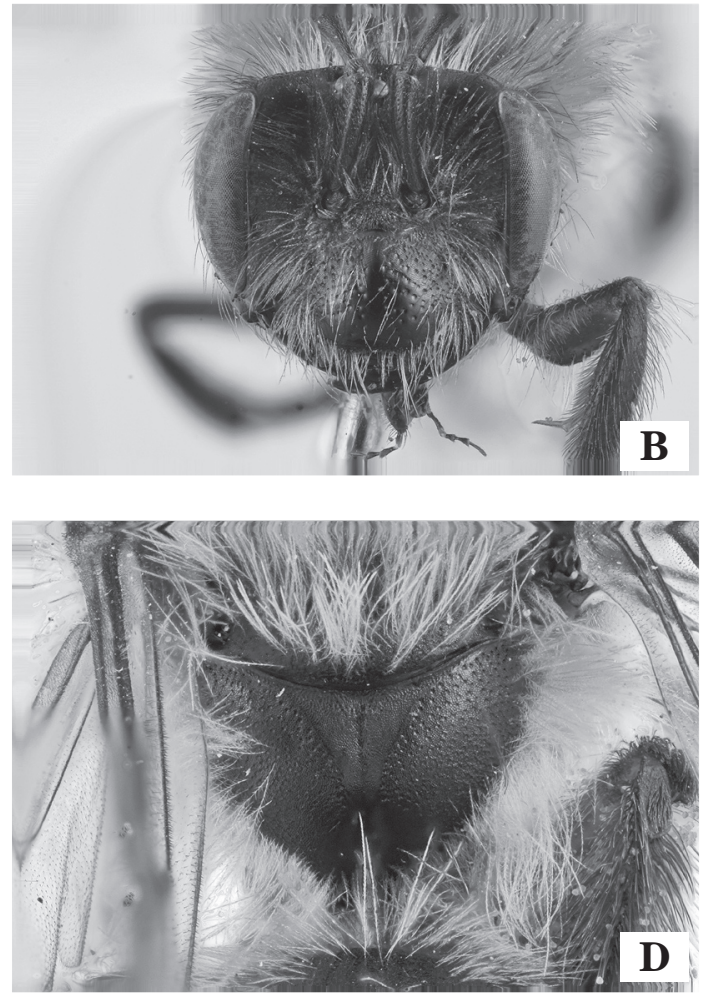

D

Fig. 6. Andrena (Andrena) kunmingica, n. sp., female. A: general habitus in dorsal view; B: head in frontal view; C: mesoscutum; D: propodeum; E: metasomal terga.

Clypeus strongly convex, surface weakly tessellate basally and laterally, smooth and shiny medioapically with scattered weak large PP $\phi 20-40 \mu$, irregular in distribution, with median polished broad longitudinal impunctate line, $\mathrm{CPL}=1.2 \mathrm{~mm}$. Process of labrum large, deeply emarginate apically, surface smooth and shiny. Labrum apical to process with median crista. Lower paraocular area with scattered minute PP, weakly shiny. Malar space distinct, about one-fourth as long as width of basal mandible. Genal area broader than eye, GW: $\mathrm{EW}=1.1$ : 0.9, surface reticularly shagreened, weakly shiny with obscure PP. Mesosoma: Pronotum with weak humeral angle and ridge, reticularly shagreened. Mesoscutum densely tessellate, weakly punctate medially with obscure minute PP. Scutellum sculptured as in mesoscutum, but shiner anteriorly. Propodeal enclosure finely granulate, with a median longitudinal suture extending to basal half; dorsal face of propodeum densely tessellate with sparse minute PP. Mesepisternum finely granulate as in propo- deal enclosure, scattered minute PP. Vein 1st $m-c u$ meeting second submarginal cell near end of cell. Metasoma: Metasomal terga densely tessellate, impunctate, posterior depressions of terga not well indicated; pygidial plate $\mathrm{V}$-shaped with raised internal triangular area. Sterna 2-5 weakly tessellate, shiny with sparse minute $\mathrm{PP}, \mathrm{IS}=2$ or more.

Male: Unknown.

Type material: Holotype female, Kunming city, 1,900 m, Yunnan Province, China, 24. iii. 1958 (X-w, Meng).

Remarks: This species is similar to Andrena lapponica Zett. in having the broad facial fovea and the yellow hairs on thorax. The female is separated from that of lapponica by the longer first flagellar segment, the clypeus strongly convex with sparse PP, and the broad labral process with deeply emarginated apex.

Distribution: China (Yunnan Prov.). 
Floral association: Not available.

\section{3-1.Andrena (Andrena) lapponica shirozui Hirashima}

Andrena (Andrena) shirozui Hirashima, 1962, J. Fac. Agr., Kyushu Univ., 12: 143 [female, Japan]; Hirashima, 1966, J. Fac. Agr., Kyushu Univ., 12: 103 [female, in key].

Andrena (Andrena) lapponica shirozui: Tadauchi, Hirashima et Matsumura, 1987, J. Fac. Agr., Kyushu Univ., 31: 42-44 [male, Japan]; Osytshnjuk, 1995, Key Insects Russian Far East, Vol. IV, Part 1, 514, 522 [female \& male, in key].

Specimen examined: Holotype female (Kyushu Univ.), Nukabira, Tokachi, Hokkaido, Japan, 4-5. vii. 1957 (R. Ishikawa).

Distribution: Japan (Hokkaido, Honshu); Russia (Far East area).

Floral association: Taraxacum officinale, Gerum pentapetalum.

\section{3-2. Andrena (Andrena) lapponica sumizome Tadauchi, Hirashima et Matsumura}

Andrena (Andrena) lapponica sumizome Tadauchi, Hirashima et Matsumura, 1987, J. Fac. Agr., Kyushu Univ., 31: 44 [female, Japan].

Specimen examined: Holotype female (Kyushu Univ.), Gonoike, Mt. Ontake, 23. vi. 1976 (K. Yamauchi).

Distribution: Japan (alpine region, central Honshu).

Floral association: Not available.

\section{Andrena (Andrena) longitibialis Hirashima}

Andrena (Andrena) longitibialis Hirashima, 1962, J. Fac. Agr., Kyushu Univ., 12: 139-141 [female, Japan]; Hirashima, 1966, J. Fac. Agr., Kyushu Univ., 12: 102, 106 [female \& male, in key]; Tadauchi et al., 1987, J. Fac. Agr., Kyushu Univ., 31: 38-39; Tadauchi and Lee, 1992, Esakia, (32): 49 [Korea]; Gusenleitner and Schwarz, 2002, Entomofauna, 12(suppl.): 441.

Specimen examined: Holotype female (Kyushu Univ.), Nasu, Yumoto, Honshu, Japan, 21. v. 1958 (R. Ishikawa).

Distribution: Japan (Hokkaido, Rishiri Is., Honshu, Sado Is., Shikoku, Kyushu); Korea (southern Korea).

Floral associations: Tadauchi et al. (1987) listed 14 plants.

\section{Andrena (Andrena) helvola Linnaeus}

Apis helvola Linnaeus, 1758, Syst. Nat., 10 (1): 575 [female, Europe].

Andrena helvola: Stöckhert, 1930, Hym. Nord-und Mitteleurop., 925, 963 [female \& male, in key].

Andrena (Andrena) helvola: Gusenleitner and Schwarz, 2002, Entomofauna, 12(suppl.): 339-340.

Specimen examined: China: Heilongjiang Province: 1 female, Jingpo Lake, Mudanjiang, 23. v. 1993 (O.
Tadauchi).

Remarks: This specimen is different from European helvola in the metasomal terga slightly punctate. It can be separated from the European Andrena praecox (Scopoli) by the clypeus broadly smooth and shiny with sparse PP and the propodeal enclosure weakly rugulate basally.

Distribution: China (new record, Heilongjiang Prov.); Europe.

Floral association: China: Not available.

\section{Andrena (Andrena) maukensis Matsumura}

Andrena maukensis Matsumura, 1911, J. College Agr. Tohoku Imp. Univ., 4: 107 [female, Japan]; Yasumatsu, 1941, Peking nat. Hist. Bull., 15: 277 [in list].

Andrena (Andrena) maukensis: Hirashima, 1962, J. Fac. Agr., Kyushu Univ., 12: 142; Hirashima, 1966, J. Fac. Agr., Kyushu Univ., 12: 103 [female in key]; Tadauchi et al., 1987, J. Fac. Agr., Kyushu Univ., 31: 37-38 [male]; Osytshnjuk, 1995, Key Insects Russian Far East, Vol. IV, Part 1, 514, 522 [female \& male, in key]; Gusenleitner and Schwarz, 2002, Entomofauna, 12(suppl.): 463-464.

Specimen examined: Holotype female (Hokkaido Univ.), Saghalin, Oguma.

Distribution: Japan (Hokkaido, Honshu, Kyushu); Russia (Far East Area).

Floral association: Taraxacum officinale; Solidago virgaurea leiocarpa; Salix taraikensis.

\section{Andrena (Andrena) aburana Hirashima}

Andrena (Andrena) aburana Hirashima, 1962, J. Fac. Agr., Kyushu Univ., 12: 146-149 [female \& male, Japan]; Hirashima, 1966, J. Fac. Agr., Kyushu Univ., 14: 103, 116 [female \& male, in key]; Tadauchi et al., 1987, J. Fac. Agr., Kyushu Univ., 31: 44-45; Gusenleitner and Schwarz, 2002, Entomofauna, 12(suppl.): 54-55.

Specimens examined: Holotype male and allotype female (Kyushu Univ.), Mt. Homan, Fukuoka Pref., Kyushu, Japan, holotype, 18. iii. 1951 (Y. Hirashima); allotype, 19. iv. 1931 (K. Yasumatsu). Other material: China: Jilin Province: 4 females, Baihe, Changbaishan, 25-28. vii. 1986 (X-l. Meng); 1 female, Manjiang, 31. v. 1955 .

Distribution: China (new record, Beijing, Jilin Prov.); Japan (Honshu, Sado Is., Shikoku, Kyushu).

Floral association: Japan: Brassica napus; Prunus mume; Salix sp.

\section{Andrena (Andrena) katakuri Tadauchi et Goubara}

Andrena (Andrena) katakuri Tadauchi et Goubara, 2011, Esakia, (50): .23-26 [female \& male, Japan].

Specimens examined: Holotype female (Kyushu Univ.), Yasawa, Hanamaki, Iwate Pref., 11. iv. 2003 (T. Chiba). Paratypes male: same locarity and collector as 
the holotype: 2 males, 3. iv. 2003.

Distribution: Japan (Honshu: Iwate Pref.).

Floral association: Erythronium japonicum Dacne, Veronica persica Poiret, Salix sp.

\section{ACKNOWLEDGEMENTS}

We are grateful to Emeritus Prof. Y. Hirashima and Prof. J. Yukawa of Kyushu University for their useful suggestions, to Associate Prof. L. Westover of Kyushu University for reading the manuscript. This research was supported by the National Natural Science Foundation of China (No. 30970412) and Special Fund for Agroscientific Research in the Public Interest (No. 201203080) to H-l. Xu and by the Environment Research and Technology Development Fund (S-9-2(8)) of the Ministry of the Environment, Japan to O. Tadauchi. This is a contribution from the Entomological Laboratory of Kyushu University (Ser.6, No. 107).

\section{REFERENCES}

Ascher, J. S. and J. Pickering 2011 Discover life bee species guide and world checklist (Hymenoptera: Apoidea: Anthophila). http://www.discoverlife.org/mp/20q?guide=Apoidea_species.

Grünwaldt, W., A. Z. Osytshnjuk and E. Scheuchl 2005 Neue Andrena-Arten aus der Paläarktis (Hymenoptera: Apidae: Andreninae). Entomofauna, 26(19): 346-368

Gusenleitner, F. and M. Schwarz 2002 Weltweite Checkliste der Bienengattung Andrena mit Bemerkungen und Ergänzungen zu paläarktischen Arten (Hymenoptera, Apidae, Andreninae, Andrena). Entomofauna, Suppl., 12: 1-1280 (in German)

Hedicke, H. 1933 Beiträge zur Systematic der Gattung Andrena F. (Hym. Apid.). Mitteil. Zool. Mus. Berlin, 19: 199-220

Hirashima, Y. 1957 Descriptions and records of bees of the genus Andrena from Eastern Asia. III (Hymenoptera, Andrenidae). Mushi, 30: 49-57

Hirashima, Y. 1962 Systematic and biological studies of the family Andrenidae of Japan (Hymenoptera, Apoidea). Part 2. Systematics, 1. J. Fac. Agr., Kyushu Univ., 12: 117-154

Hirashima, Y. 1964 Systematic and biological studies of the family Andrenidae of Japan (Hymenoptera, Apoidea). Part 2. Systematics, 4. J. Fac. Agr., Kyushu Univ., 13: 39-69
Hirashima, Y. 1966 Systematic and biological studies of the family Andrenidae of Japan (Hymenoptera Apoidea). Part 2. Systematics 7. J. Fac. Agr., Kyushu Univ., 14: 89-131

Lanham, U. N. 1949 A subgeneric classification of the New World bees of the genus Andrena. University of California Press, Berkeley and Los Angeles

LaBerge, W. E. 1964 Prodromus of American bees of the genus Andrena (Hymenoptera, Apoidea). Bull. Univ. Nebraska State Mus., 4(14): 279-316

LaBerge, W. E. 1980 A revision of the bees of the genus Andrena of the Western Hemisphere. Part X. Subgenera Andrena. Trans. Amer. Entomol. Soc., 106: 395-525

Osytshnjuk, A. Z. 1995 Andrena. In "Key to the insects of Russian Far East in six volumes. vol. 4, Neuropteroidea, Mecoptera, Hymenoptera, Part 1", ed. by P. A. Lehr, St. Petersburg, Nauka, pp. 489-527 (In Russian)

Tadauchi, O., Y. Hirashima and T. Matsumura 1987 Synopsis of Andrena (Andrena) of Japan (Hymenoptera, Andrenidae). Part I and II. J. Fac. Agr., Kyushu Univ., 31: 11-35, 37-54

Tadauchi, O. and M. Goubara 2011 A new species of the genus Andrena from Japan (Hymenoptera, Andrenidae). Esakia, (50): $23-26$

Tadauchi, O. and C. E. Lee 1992 The family Andrenidae of Korea (Hymenoptera, Apoidea).1. Esakia, (32): 47-58

Tadauchi, O. and T. Matsumura 2007 The genus Andrena collected from Nepal (Hymenoptera, Andrenidae) with redescription of some types of Andrena described from north India Esakia, (47): 1-20

Warncke, K. 1968 Die Untergattungen der westpaläarktischen Bienen-gattung Andrena F. Mem. Est. Mus. Zool. Univ. Coimbra, (307): 1-111

Wu Y-r. 1982 Hymenoptera: Apoidea. In "Insects of Xizang", Vol. II, ed. by F-s. Huang, Science Press, Beijing, pp. 379-426

Wu, Y-r. 1985 Hymenoptera: Apoidea. In "Living Things of Tianshan Tumorfeng Region of Xinjiang". Xinjiang People Press, Wulumuqi, pp. 137-150

Wu, Y-r. 1988 Hymenoptera: Apoidea. In "Insects of Mt. Namjagbarwa Region of Xizang". Science Press, Beijing, pp. $545-552$

$\mathrm{Xu}, \mathrm{H}-\mathrm{l}$. and O. Tadauchi 1998 Subgeneric positions and redescriptions of Strand's Chinese Andrena preserved in the German Entomological Institute (D.E.I., Eberswalde) (Hymenoptera: Andrenidae). Esakia, (38): 89-103

Yasumatsu, K. 1940-41 A list of the Far Eastern species of the genus Andrena (Hym., Apoidea). Peking Nat. Hist. Bull., 15(4): $273-284$ 